\title{
MEASURING THE STATE OF DISASTER PHILANTHROPY

\section{DATA TO DRIVE DECISIONS}
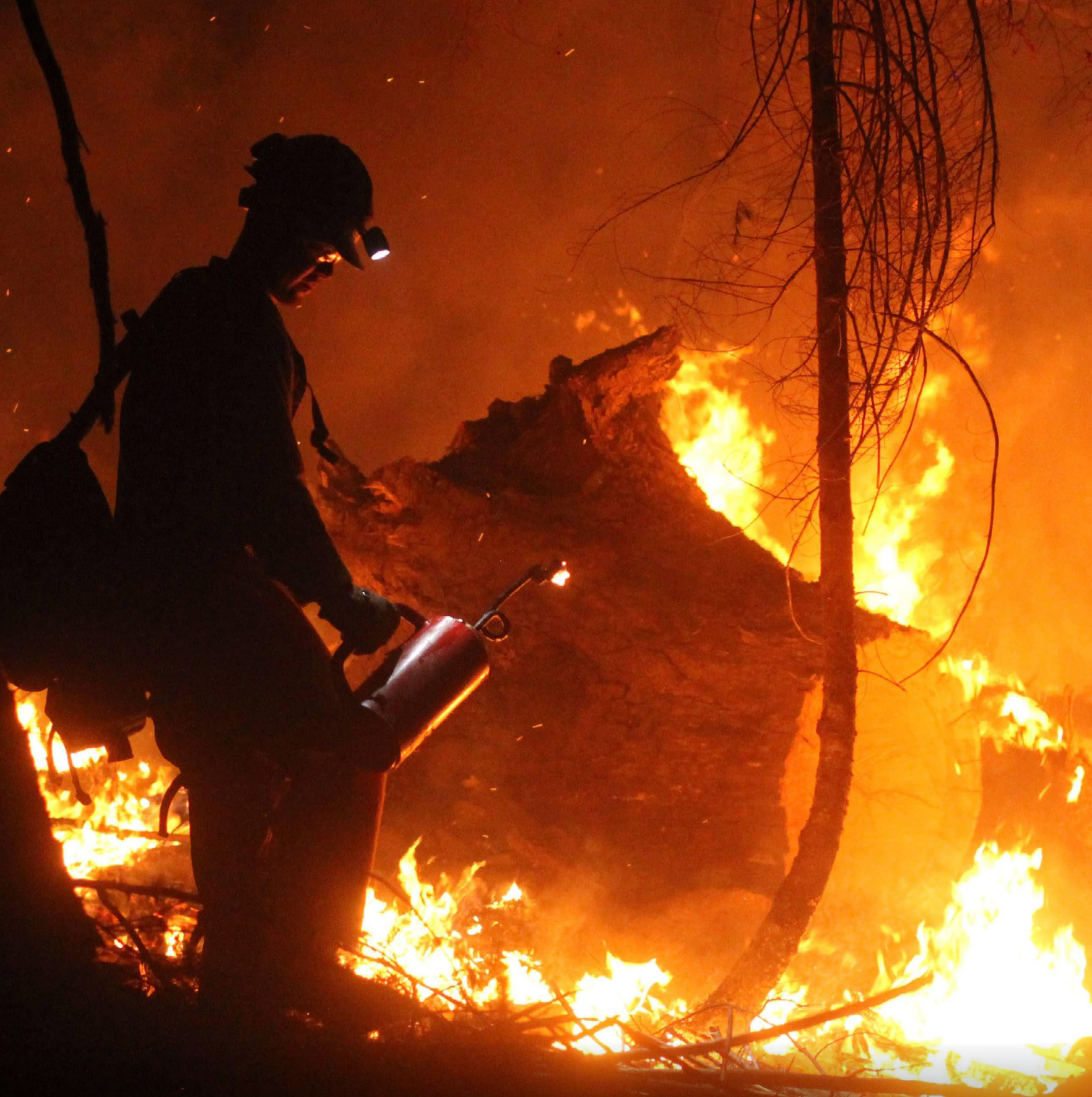


\section{Executive Summary}

Disasters and humanitarian crises affected millions of people globally in 2018. Hurricane Florence's torrential rain and flooding caused catastrophic damage within the Carolinas in the United States, only to be followed by Hurricane Michael, which caused devastation in the U.S. and parts of Central America. In September, a 7.5 magnitude earthquake struck Indonesia's Central Sulawesi province, triggering a tsunami and landslides that caused widespread destruction and loss of life. Famines in Africa and civil unrest in Syria and Yemen continued, further increasing the number of refugees, asylum seekers, and internally displaced people.

In 2018, we saw not one but three volcanic eruptions take place, one in Hawaii followed by one in Guatemala and one in Indonesia. California experienced its most devastating wildfire event in terms of loss of life with the Camp Fire, and Typhoon Mangkhut caused extensive damage in Guam, the Philippines, and southern China. The Rohingya crisis worsened as millions of refugees escaped to Bangladesh, only to be stuck in overcrowded camps in Cox's Bazar.

Each year, the Center for Disaster Philanthropy (CDP) and Candid examine global disaster-related funding from foundations, bilateral and multilateral donors, the U.S. federal government, and corporations and donations through donor-advised funds and online platforms. We analyze funding according to a taxonomy that classifies giving by type of disaster and disaster assistance strategy.

As the world continues to cope with the COVID-19 pandemic while addressing record-breaking wildfires in California and other parts of the U.S., Siberia, and the Amazon as well as another devastating hurricane season, what lessons can we take from the philanthropic response to disasters in 2018 ?

Key findings from our 2018 analysis include:

- Drawing upon 13 data sources, we documented almost $\$ 76$ billion in disaster-related giving in 2018.

- We specifically identified $\$ 468$ million in funding by foundations and public charities for disasters and humanitarian crises, based on Candid's database; this figure includes transactions by U.S. and non-U.S. donors.

- Natural disasters accounted for 52 percent of this disaster funding. Support continued for those impacted by 2017 hurricanes and addressed 2018 Hurricanes Florence and Michael.
- Among disaster assistance strategies, 50 percent of dollars were for response and relief efforts. Twelve percent went toward reconstruction and recovery, a majority of which was focused on storm recovery. A mere 2 percent was allocated for resilience measures and 4 percent for disaster preparedness measures.

- Disaster-related funding in 2018 decreased by around $\$ 50$ million from 2017, based on a year-over-year analysis of grantmaking by 1,000 of the largest U.S. foundations.

- Official development assistance by 30 government members of the Organisation for Economic Co-operation and Development's Development Assistance Committee (DAC) totaled \$21 billion for disasters and humanitarian crises in 2018. Non-DAC government donors and multilateral organizations contributed an additional $\$ 5.6$ billion, a nearly $\$ 3.7$ billion increase from the prior year.

- The Federal Emergency Management Agency (FEMA) distributed $\$ 11.2$ billion for U.S. disasters in 2018, a $\$ 4.4$ billion decrease from 2017, which was a record-breaking year for natural disasters in the United States. The U.S. Department of Housing and Urban Development (HUD) allocated $\$ 34.5$ billion in recovery efforts in 2018 for disasters that took place in 2016 and 2017, a substantial $\$ 31.8$ billion increase from 2017. In 2018, the U.S. Economic Development Administration (EDA, our newest data contributor) invested approximately $\$ 125.6$ million in 67 projects for disasters that took place in 2017. This is just a sampling of U.S. government contributions that make up the bulk of disaster funds.

- Based on available data, corporate giving programs committed approximately \$206 million to disasters and humanitarian crises, through both cash and in-kind donations.

- Among individual donors:

- Data from a survey of U.S. households, conducted by Candid, the Center for Disaster Philanthropy, and the Indiana University Lilly Family School of Philanthropy, indicates that 29 percent of U.S. households made a disaster-related donation in $\mathbf{2 0 1 8}$, averaging $\$ 83$. We can infer from this amount that U.S. households may have donated roughly $\$ 3$ billion to disaster aid efforts in 2018.

- Individual donors contributed \$25.2 million through donoradvised funds managed by Fidelity Charitable and $\$ 9.2$ million through donor-advised funds managed by 
Vanguard Charitable. These numbers provide only a small snapshot of contributions made through donor-advised funds, as Fidelity Charitable and Vanguard Charitable are just two of many donor-advised fund management companies.

- Many individual donors also gave through online platforms, including Network for Good and GlobalGiving. Network for Good helped direct $\$ 10.3$ million in donations to disasterspecific nonprofits in 2018. GlobalGiving raised $\$ 9$ million for disasters, supporting 276 projects in 2018.

Disaster philanthropy in 2018 continues to offer benefits today. The Community Organized Relief Effort (CORE) used a 2018 CDP grant to work with the Lumbee tribe to retrofit buildings and prepare emergency evacuation plans. These measures enabled the tribe to withstand Tropical Storm Isaias with far less damage this year.
In California, a 2018 CDP California Wildfires Recovery Fund grant after the Camp Fire has allowed the North Valley Community Foundation to provide on-going school-based counselors to support trauma recovery for children in Paradise and other districts.

Philanthropy plays a crucial role in supporting long-term recovery of individuals and communities impacted by disasters. Local community foundations, in particular, are positioned to assist their communities during the many ongoing years of recovery after a disaster has passed. Philanthropy can also support preparedness and mitigation to help reduce the overall impact of disasters.

We hope this analysis assists donors as they consider how to maximize the impact of their disaster-related giving. To learn more about Measuring the State of Disaster Philanthropy, we invite you to visit our online tools - including an interactive funding mapat disasterphilanthropy.candid.org.

\section{Philanthropy and COVID-19}

Although this report examines disaster giving in 2018, we cannot disregard the current crisis the globe is responding to, the COVID-19 pandemic. At the same time that funders and NGOs are still trying to rebuild communities impacted by the disasters in 2018, they are being hindered by the restrictions that COVID-19 imposes. In August 2020, Candid and the Center for Disaster Philanthropy explored trends in philanthropic giving related to the COVID-19 pandemic in the first half of 2020. We documented $\$ 11.9$ billion in global philanthropy for COVID-19 in the first six months of the year, and we are continuing to track the funding flows.

The report revealed that foundations and individual donors stepped up to meet immediate needs and services arising from the pandemic. Disproportionately little funding by foundations and public charities directed to specified recipients, however, was explicitly designated for persons and communities of color, which have been hit hard by the virus. You can read the full report here: doi.org/10/gg72df
Funding for the pandemic is larger than anything we've seen since we began collecting realtime data about disasters and humanitarian crises. And yet we know there's more global COVID-19 philanthropy we haven't captured. We will be Philanthropy and COVID-19 in the first half of 2020 releasing an update to this report in March 2021. If you're a funder, it is not too late to have your data included in the analysis. Learn more about how you can contribute to the global database of philanthropy for COVID-19. 


\section{Disaster Philanthropy in 2018}

Philanthropic funding for disasters and humanitarian crises is situated within a large ecosystem of global aid. Although assistance from governments far surpasses funding from foundations, institutional giving and individual philanthropy still play important roles. When making funding decisions, foundations and highwealth donors can choose to fill gaps and support underfunded areas of the disaster lifecycle. Support for disaster risk reduction and preparedness mitigates the impact of disasters, and many communities need sustained funding for the long road to recovery.
What was the landscape of philanthropic giving to disasters in 2018? This report documents foundation support and places it in context with other sources of national and global aid to provide the fullest possible financial picture of disaster-related funding.

We acknowledge there are far more disaster contributions than those we currently document. We invite donors, government agencies, and other data-gathering organizations to partner with us to include their giving data in our annual analysis: disasterphilanthropy.candid.org/ get-involved.

\section{DATA SOURCES}

\section{DESCRIPTION}

CANDID

ORGANISATION FOR ECONOMIC CO-OPERATION AND DEVELOPMENT (OECD) CREDITOR REPORTING SYSTEM UNITED NATIONS OFFICE FOR THE COORDINATION OF HUMANITARIAN
AFFAIRS (UN OCHA) FINANCIAL TRACKING SERVICE

U.S. FEDERAL EMERGENCY MANAGEMENT AGENCY (FEMA)

U.S. DEPARTMENT OF HOUSING AND URBAN DEVELOPMENT (HUD)

U.S. ECONOMIC DEVELOPMENT ADMINISTRATION (EDA)

CHIEF EXECUTIVES FOR CORPORATE PURPOSE (CECP)

U.S. CHAMBER OF COMMERCE FOUNDATION CORPORATE CITIZENSHIP CENTER DISASTER CORPORATE AID TRACKERS

FIDELITY CHARITABLE

VANGUARD CHARITABLE

NETWORK FOR GOOD

GLOBALGIVING
Comprehensive source of data on U.S. philanthropic giving with a growing database of global foundations

Central database for official development assistance from the 30 OECD Development Assistance Committee (DAC) member states

Comprehensive source of real-time humanitarian aid contributions; to avoid double counting, we exclude contributions from

DAC donors and U.S. foundations

Detailed information on domestic grants by this U.S. government agency for disasters

Aggregated data on disbursements made by this U.S. government agency for disasters

Aggregated data on disbursements made by this U.S. government agency for disasters

Aggregated data on contributions made by corporations, based on CECP's Giving in Numbers report

Key source of data on corporate giving for disasters

Aggregated data on contributions collected through donor-advised funds

Aggregated data on contributions collected through donor-advised funds

Aggregated data on disaster-designated contributions collected through its software platform

Disaster-related contributions collected through the organization's online giving platform

Online survey to estimate disaster giving by U.S. households for 2017 and 2018 conducted in March 2019 by Indiana University Lilly Family School of Philanthropy, Center for Disaster Philanthropy, and Candid 


\section{Disaster Taxonomy}

\section{DISASTER TYPES}

\section{COMPLEX HUMANITARIAN EMERGENCY}

MAN-MADE ACCIDENT

GENERAL

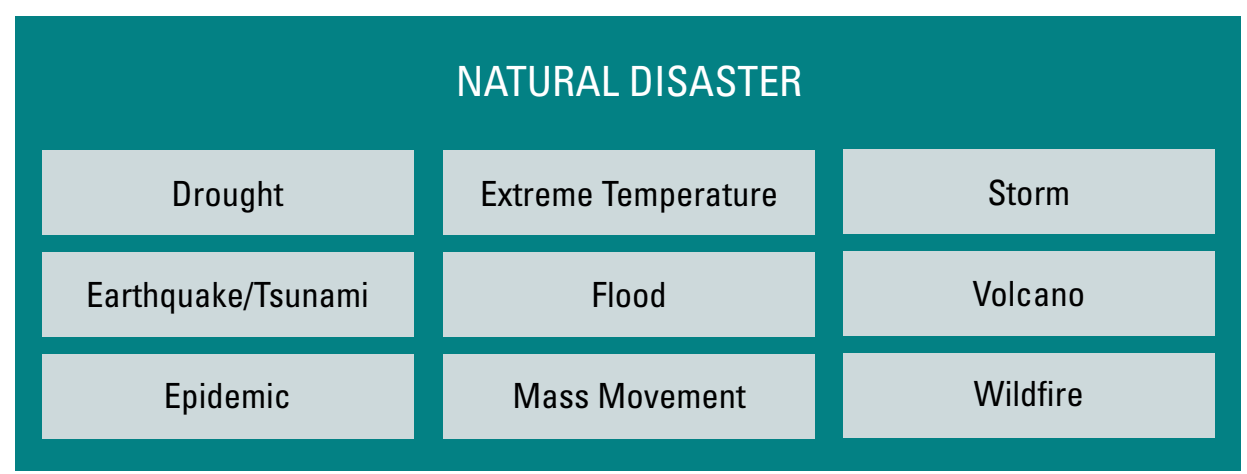

\section{DISASTER ASSISTANCE STRATEGIES}

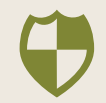

RESILIENCE, RISK REDUCTION, AND MITIGATION

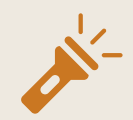

PREPAREDNESS

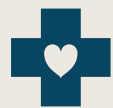

RESPONSE AND RELIEF

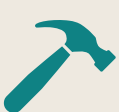

RECONSTRUCTION AND RECOVERY

\section{About This Project}

Measuring the State of Disaster Philanthropy is an annual analysis of funding for global disasters and humanitarian crises. See these other tools to help inform disaster-related philanthropy:

\section{MEASURING THE STATE OF DISASTER PHILANTHROPY DASHBOARD}

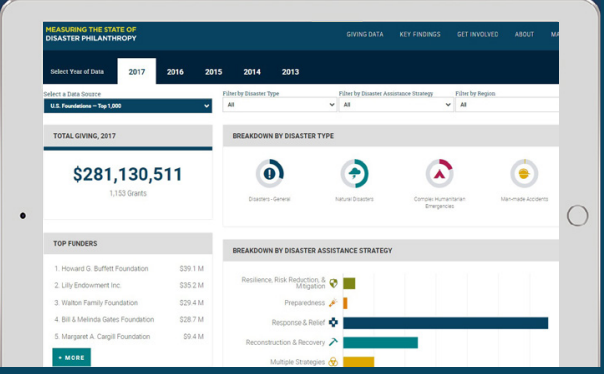

Interact with aggregated 2018 funding data and compare with previous years disasterphilanthropy.candid.org
MEASURING THE STATE OF DISASTER PHILANTHROPY MAPPING PLATFORM

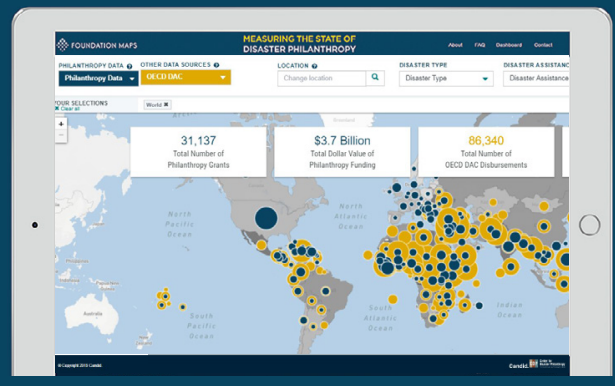

Dig deeper into grant- and project-level data from 2011 to the present disasterphilanthropy.candid.org/map
DISASTER PHILANTHROPY PLAYBOOK

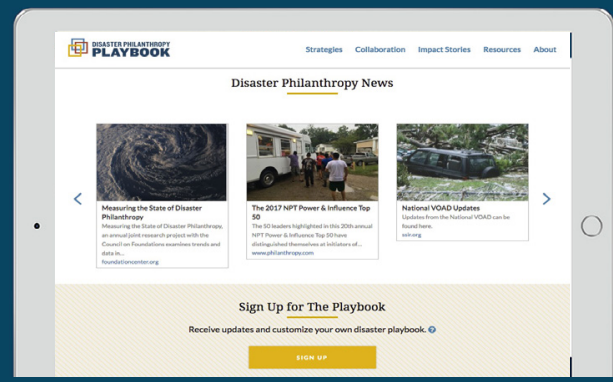

Learn about the best ways to allocate resources for disasters disasterplaybook.org

For more information about this report, or to learn how to increase the effectiveness of your philanthropic dollars, please contact tanya.gulliver-garcia@disasterphilanthropy.org 


\section{Institutional Philanthropy}

\section{PHILANTHROPIC FUNDING BY DISASTER TYPE, 2018}

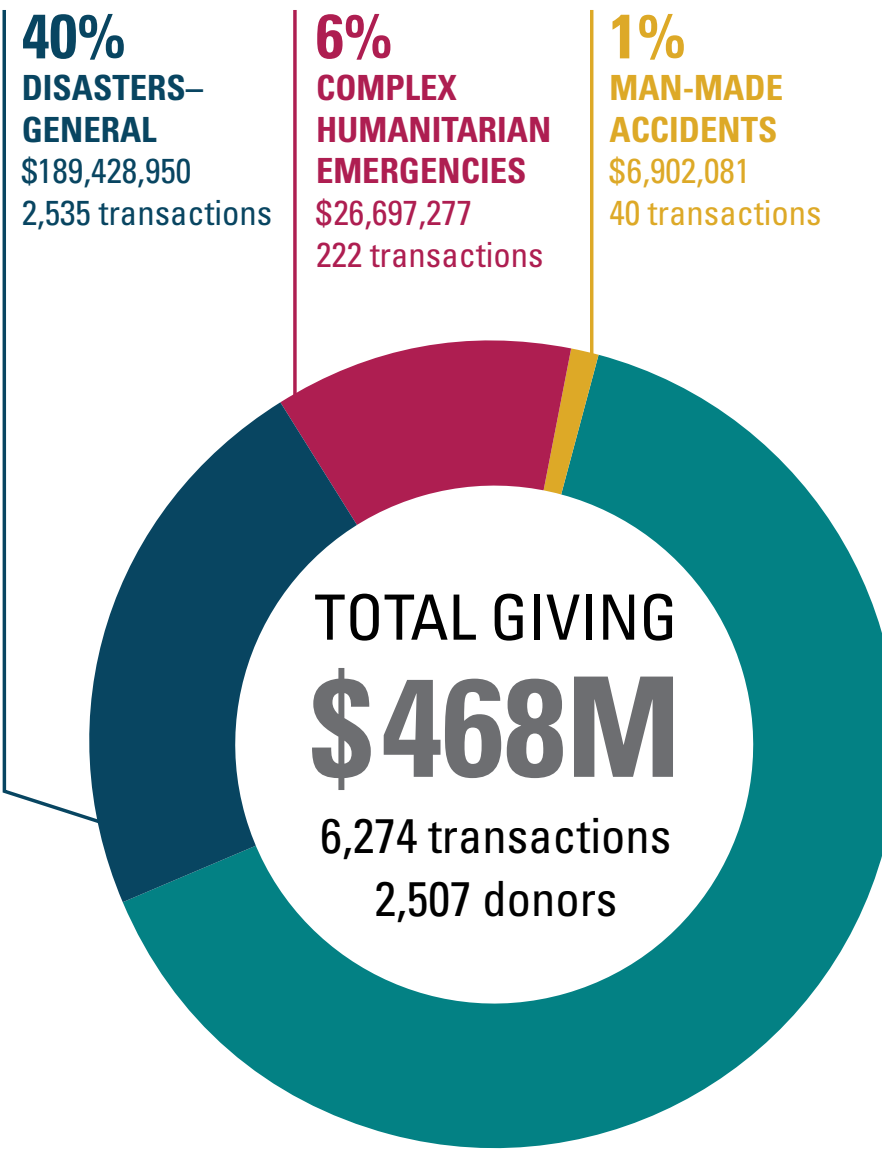

Funding for complex emergencies as a proportion of overall disaster funding declined compared to previous years.

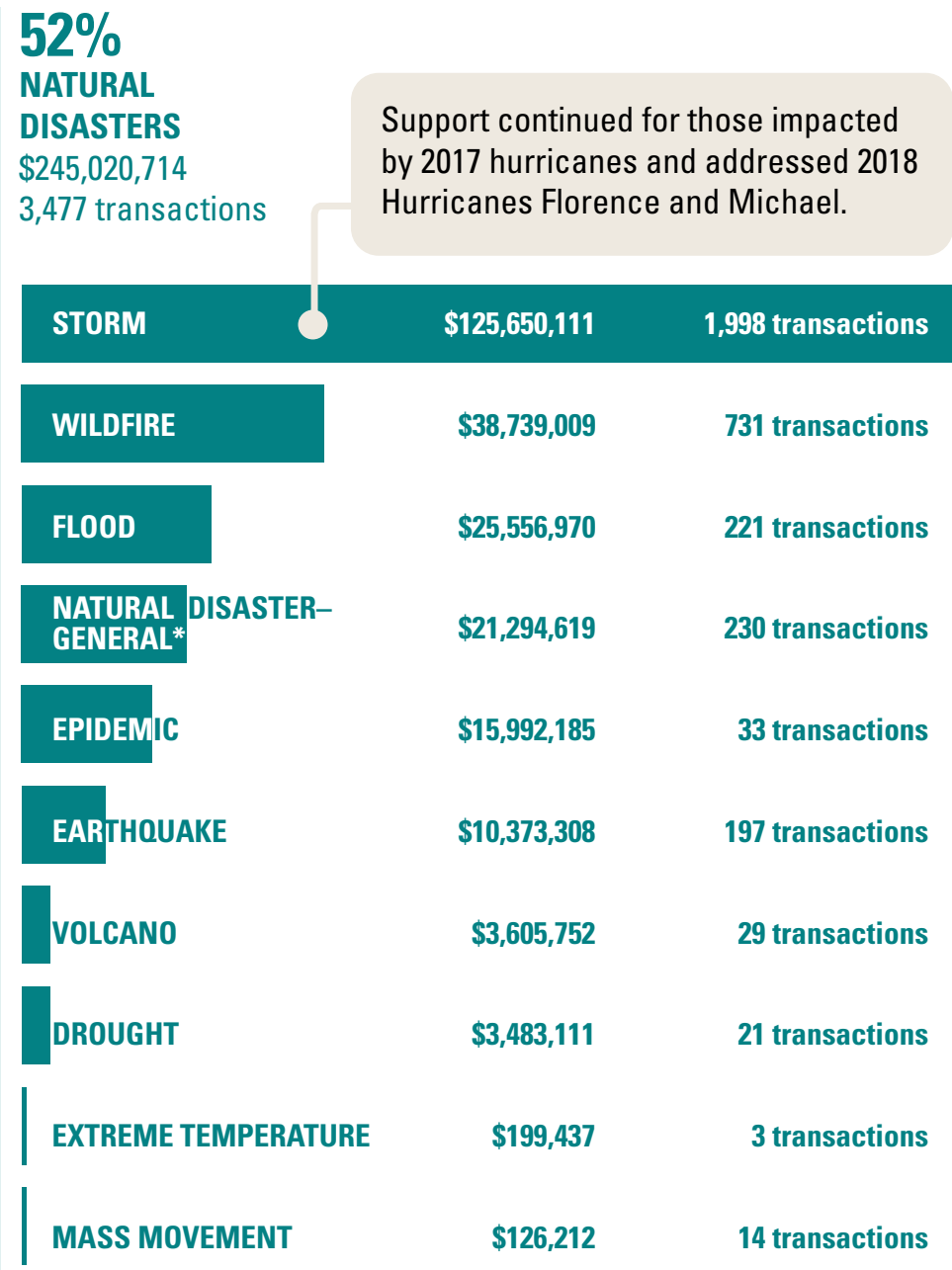

*Includes grants for general or multiple natural disasters

\section{About the Data}

This analysis is based on Candid's database as of September 29, 2020. The data set includes grants, foundation-administered programs, and program-related investments from fiscal year 2018; grants to individuals are excluded. For community foundations, discretionary grants are included as well as donor-advised grants when provided by the foundation. To avoid double-counting transactions, grants to grantmakers in the data set are excluded, except in the lists of top grantmakers and recipients. Some transactions included in the analysis are pledges for support announced in the news or by press releases. Of the total funding, $\$ 19.1$ million from 79 transactions is based on data collected in this manner. Because the data is drawn from a broader database than in prior years, we caution against making comparisons of funding dollars with previous years. For an analysis of trends, please see page 12 . 


\section{CORE-Hurricane Florence}

Formerly known as the J/P-Haitian Relief Organization, the Community Organized Relief Effort (CORE) has brought its international response and recovery experience to domestic disasters in the U.S. CORE has invested in preparedness and disaster response in hurricane-prone areas of the country. Understanding that far too often, relief does not reach vulnerable populations and those with the highest needs, CORE uses a social justice lens to guide its work.

After Hurricane Florence made landfall on September 14, 2018, CORE started working with the Lumbee tribe in Robeson County, North Carolina's most impoverished region. Despite being the largest Native American tribe east of the Mississippi River, the Lumbee tribe has never received federal support. The U.S. government does not consider it a "pure" Native American nation because of its mixed ancestry with the Black population.

The Center for Disaster Philanthropy (CDP) provided CORE's North Carolina Housing Rehabilitation and Resiliency Program (HRRP) with a $\$ 250,000$ grant to continue working with the Lumbee tribe and local municipalities to identify beneficiaries, align its program with community-driven recovery efforts, and build increased capacity. HRRP repaired and retrofitted roofs and implemented mitigation measures such as elevating HVAC units and electrical systems, installing sewage backflow valves, and creating wet-proof storage in attics. It also boosted community preparedness by supplying emergency kits and developing and providing customized evacuation protocols and information on asset protection.

According to Ann Lee, co-founder and chief executive officer of CORE, there is limited funding when CORE first arrives at a community after a disaster. Partnerships and donations from organizations like CDP provide vital funding for a crucial gap period that allows CORE to expand its work on the ground. "Having that flexibility and rapid response mentality fits with us and that timeline. We can do muck outs and quick roof repairs, then pivot to more durable solutions," Lee said.

One particularly important factor was CDP's openness to funding preparedness work, something a lot of funders do not do. "We have always been a huge proponent of preparedness. Where we're working isn't rocket science," said Lee. One aspect of the work in North Carolina that stood out for Lee involved a youth preparedness program for high-risk Black youth in Savannah, Georgia, that CORE had previously developed. "They came to North Carolina to do muck out and were forever impacted about what service can do and what it meant." The recipient families were also impacted she said. "Families that were there struggling were not from a high socio-economic status. They had nothing. They lost everything. And yet, they would come every day and feed the kids, bring water, hug them, in tears. Those are the moments - this is why we do the work."

This is an excerpt of a grantee impact story found in the Disaster Philanthropy Playbook. Read the full story here.

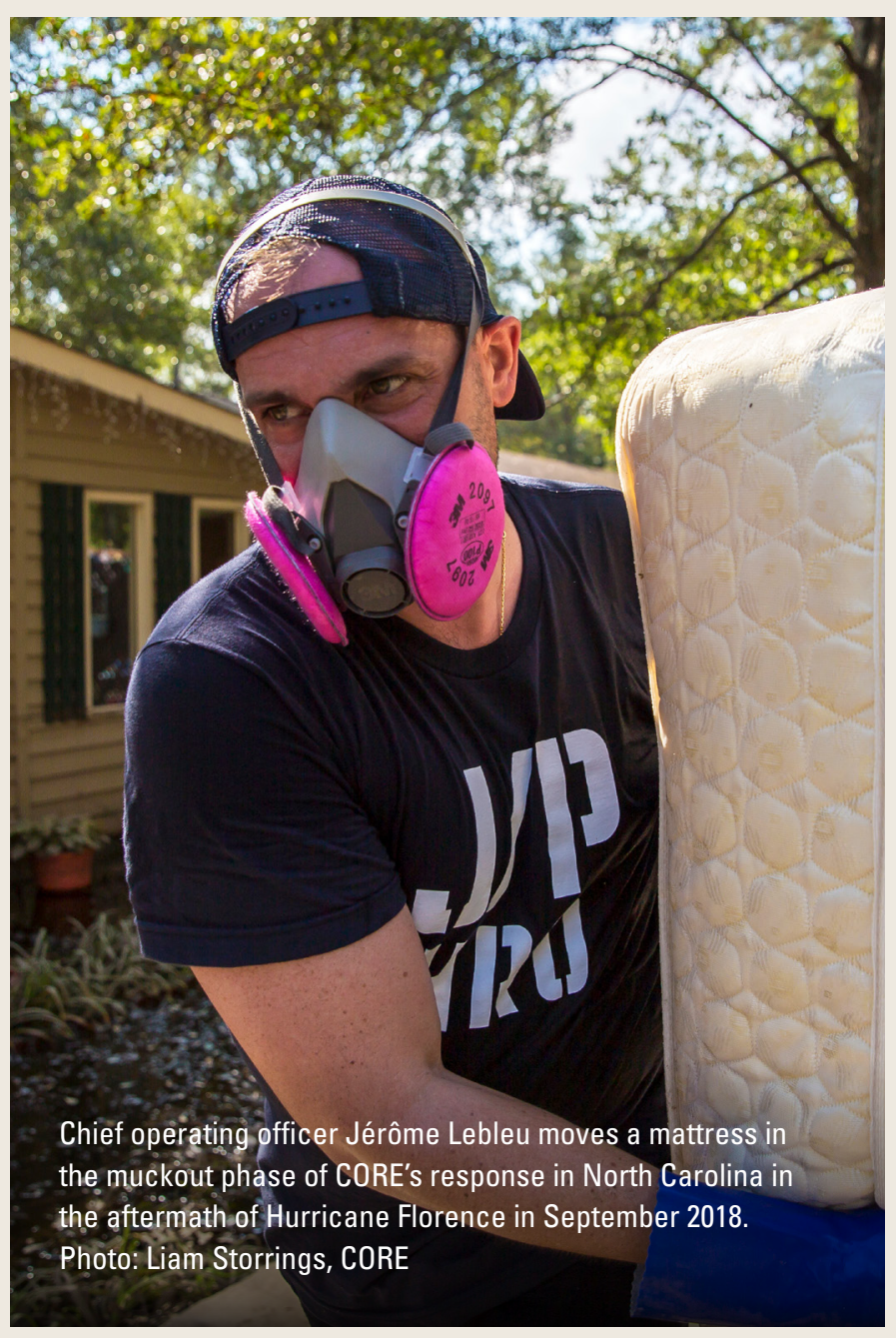




\section{PHILANTHROPIC FUNDING BY DISASTER ASSISTANCE STRATEGY, 2018}

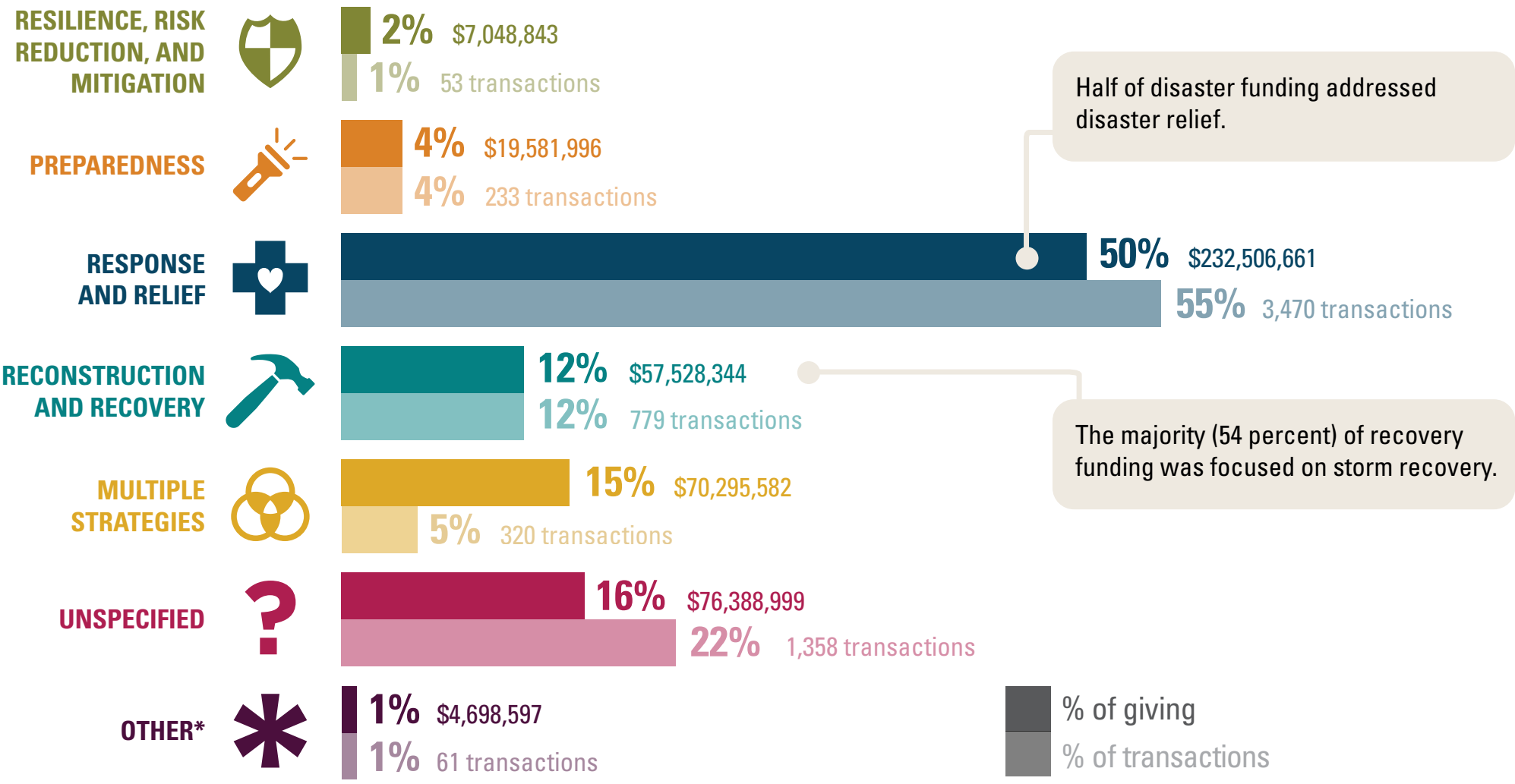

*Other includes grants for research, convenings, and other work that could not be categorized with any other assistance strategy.

\section{PHILANTHROPIC FUNDING DISTRIBUTIONS BY REGION, 2018}

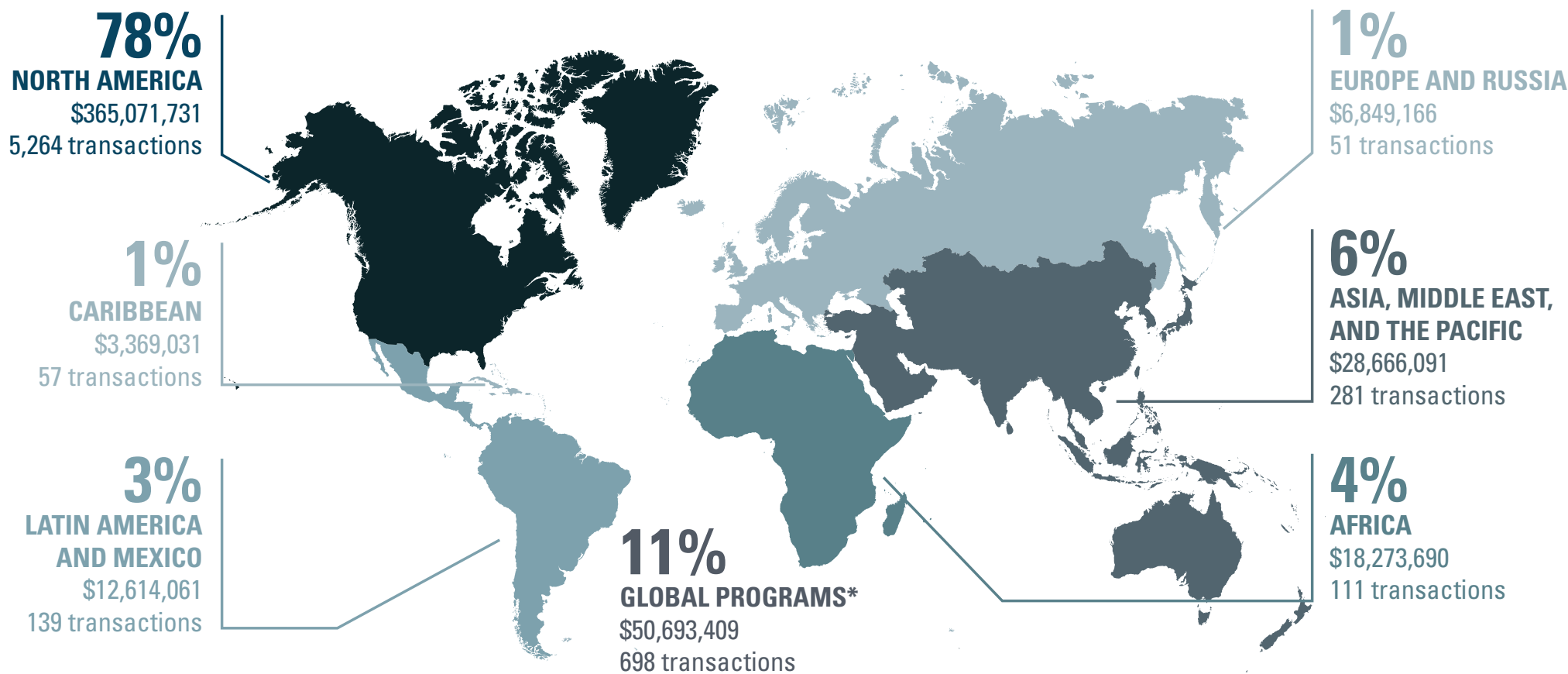




\section{Camp Fire-North Valley Community Foundation}

The Camp Fire was the deadliest and most destructive wildfire in California history, and it did nearly all of that damage in a single day. It started just before 7 a.m. on November 8, 2018, in the middle of nowhere, a place with no homes nearby. Driven by winds, including those created by the fire, it spread at the rate of a football field every second. By early afternoon, the fire had incinerated 14,000 homes including most of the town of Paradise, and significant chunks of the foothill communities of Magalia, Concow, and Butte Creek Canyon. The fire killed at least 85 people and displaced roughly 54,000 people from their homes. It took firefighters 17 days to control the wildfire.

Based on insurance losses, the Camp Fire was the world's most expensive natural disaster in 2018. Officials estimate that the fire caused approximately $\$ 16.5$ billion in damages, 25 percent of which was uninsured damages.

The Center for Disaster Philanthropy contributed a $\$ 500,000$ grant to the North Valley Community Foundation (NVCF) after the Camp Fire to provide staff support, trainings, counseling services, and capacity building across Butte County schools. In the early days of the fire, CDP also provided advice and support to NVCF to help its staff prepare for what was ahead.

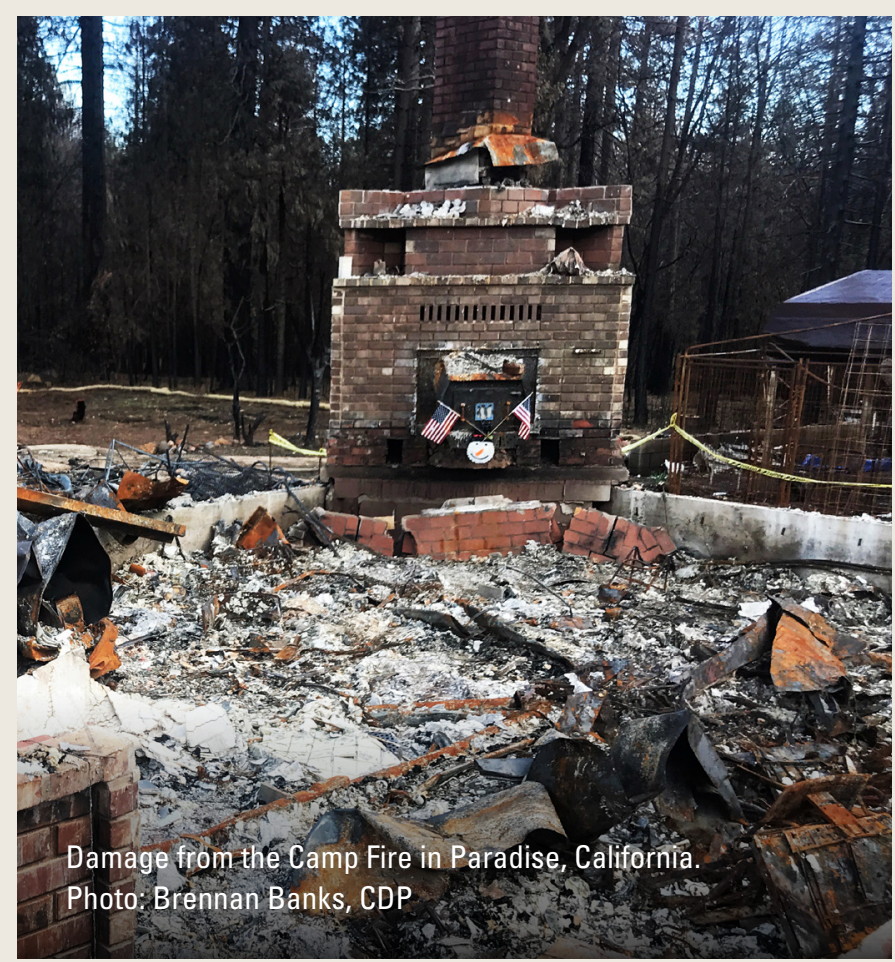

Nearly two years later, in September 2020, CDP spoke with David Little, executive vice president of programs and communications, and Kim DuFour, program officer, at NVCF. DuFour said, “CDP's advice made a huge difference with organizations such as ours and other funders who said, 'Don't spend all your money right away.' Our hearts were so broken, it was hard not to give it all away. We're in it for the long haul."

According to its website, the North Valley Community Foundation has awarded more than $\$ 35$ million in grants since the Camp Fire through the Butte Strong Fund, Camp Fire Relief Fund, and donor-designated funds. Little and DuFour said the biggest overriding concern they have had in the two years since the fire is housing. Little explains, "You just don't replace that housing overnight. While 320 homes [of the 14,000 that burned] have been rebuilt and occupied, the task remains monumental."

NVCF tried to be strategic with how it approached housing and other issues. Although it provided a lot of direct assistance, it also wanted to create permanent changes. It partnered with Samaritan's Purse on Welcome Home, an initiative that allows families to own a home mortgage free. CDP, American Red Cross, and Wells Fargo also supported this project.

The grant from CDP also allowed NVCF to hire school-based counselors in conjunction with the Butte County Office of Education to support trauma response and recovery. In its midterm report in March 2020, NVCF noted: "Suicide and suicidal ideation became much more of a concern starting in late Fall, then growing over the next several months.... The continuing magnitude of the recovery is both daunting and hopeful."

Little said, “It's incredible how far we've come because of the Center for Disaster Philanthropy and other organizations who fund us. People who stood up and said you need help. We thought people in our community would step up, but people stood up from across the country for this little community they've never heard of. For a little while, in one November, the world was looking at us. It's still bad, but we'd be so much worse off without the outside help. Our community is so grateful."

This is an excerpt of a grantee impact story found in the Disaster Philanthropy Playbook. Read the full story here. 
TOP 10 INSTITUTIONAL DONORS, 2018

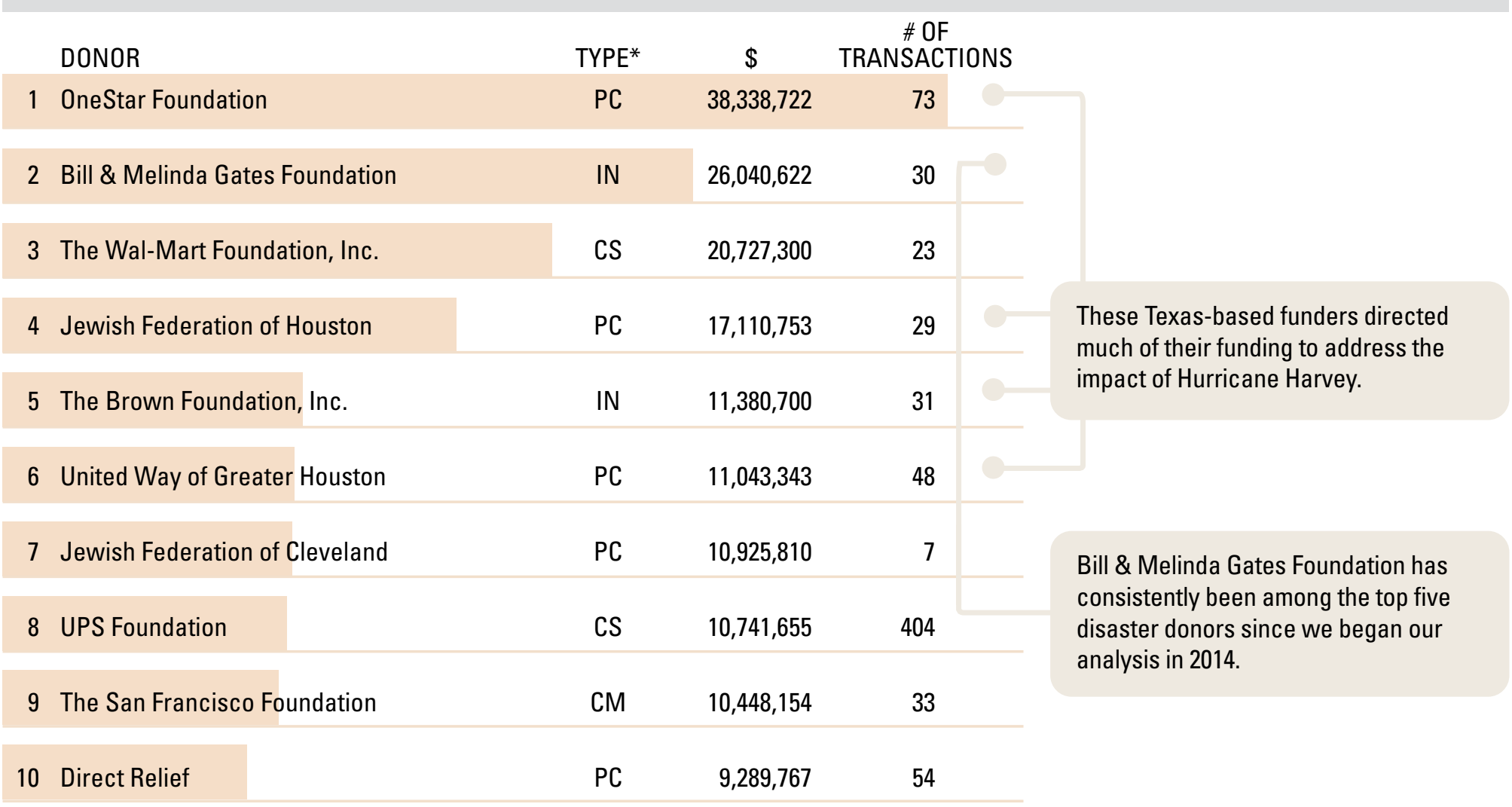

* CM=Community Foundation; CS=Corporate Foundation; IN=Independent Foundation; PC=Public Charity

\section{TOP 10 RECIPIENTS OF PHILANTHROPIC FUNDING, 2018}

\begin{tabular}{|c|c|c|c|c|}
\hline & RECIPIENT & LOCATION & $\$$ & $\begin{array}{c}\text { \# OF } \\
\text { TRANSACTIONS }\end{array}$ \\
\hline 1 & American National Red Cross & $\mathrm{DC}$ & $18,928,342$ & 233 \\
\hline 2 & Team Rubicon & CA & $10,960,783$ & 226 \\
\hline 3 & Jewish Federations of North America & NY & $10,910,200$ & 7 \\
\hline 4 & Jewish Family Service & TX & $8,722,120$ & 2 \\
\hline 5 & BakerRipley & TX & $6,800,000$ & 3 \\
\hline 6 & Puerto Rico Community Foundation & $\begin{array}{l}\text { Puerto } \\
\text { Rico }\end{array}$ & $6,354,120$ & 8 \\
\hline 7 & $\begin{array}{l}\text { International Federation of Red Cross and } \\
\text { Red Crescent Societies at the United Nations }\end{array}$ & NY & $6,286,543$ & 3 \\
\hline 8 & Community Foundation of Sarasota County & $\mathrm{FL}$ & $6,177,182$ & 1 \\
\hline 9 & Center for Disaster Philanthropy & DC & $6,107,812$ & 60 \\
\hline 10 & St. Bernard Project & LA & $5,486,352$ & 68 \\
\hline
\end{tabular}

Includes recipients who are also funders in the data set. 


\section{Hurricane Florence-Land Loss Prevention Project}

The Land Loss Prevention Project (LLPP) is a nonprofit law firm that offers legal representation, community education, and professional outreach in the effort to promote wealth, land preservation, and rural livelihoods. It assists low-resourced individuals and families statewide in North Carolina by providing direct legal representation, technical assistance, and education to protect their homes, land, farms, and rural livelihoods from loss or diminution, and to foster agricultural entrepreneurship and a healthy food system. LLPP received a $\$ 50,000$ grant from the Center for Disaster Philanthropy (CDP) to support its work following Hurricane Florence in North Carolina. CDP's grant was used to address immediate critical needs of Black homeowners, landowners, and small-scale farmers in 13 counties and reduce their disaster assistance inequality. CDP interviewed Savonala "Savi" Horne, LLPP's executive director, in September 2020 to learn more about the impact of the grant.

LLPP carried out the work for its grant in eastern North Carolina, the northernmost point of the historical Black Belt of the South. Horne said that tremendous African American land loss ironically accelerated in the years of the civil rights movements, from the 1950s to 1970s. She explained that in 1954 in North Carolina, there were 22,625 Black farmers and by 1969 that number had decreased by 57 percent to 9,687 . Black land ownership dropped from $1,085,750$ acres in 1954 by 48.5 percent to 558,861 acres in 1969. In 1978, the Census of Agriculture reported that 400,312 acres of North Carolina were Black owned. By 2017, just a year before the hurricane, this figure had decreased to 170,450 acres, with only 1,435 Black farm operators-a 57 percent drop in 40 years, three times that of white farmers.

Much of this decline can be traced to the issue of heirs' property, something that LLPP spends a great deal of time educating farmers about. A Pro Publica article explains, “Heirs' property, [is] a form of ownership in which descendants inherit an interest, like holding stock in a company." Without a legal will, heirs may not always be given access to funds after a disaster or may have their ownership challenged.

Horne explained, “LLPP addresses the impact of heirs' property ownership through legal representation, community outreach, and education. This was the most significant part of the grant from CDP. We were able to leverage field of influence and

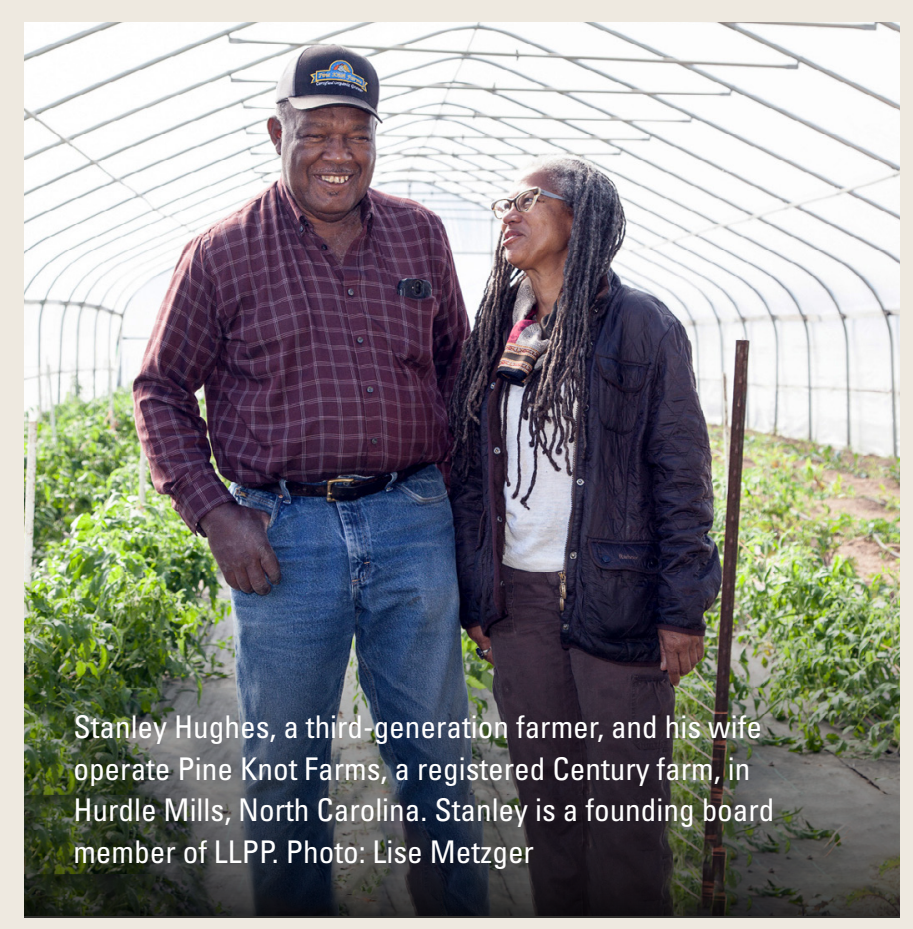

provide technical and training information for lawyers which would equip a broader community of legal practitioners to assist those in the disaster area of the state."

In addition to legal intervention, LLPP looked at best practices to stabilize Black farm ownership affected by Hurricane Florence. They worked to shore up some of the economic activities that farmers were engaging in, particularly as there were entire ecosystems that collapsed around the hurricanes. "Hurricane Florence swelled rivers far removed from the coast," Horne said. "Because let's be clear, most of the coastal communities are no longer held by African Americans because the coasts have become desirable property." Horne concluded, "It was farsighted and progressive for the Center for Disaster Philanthropy to fund a legal nonprofit to do this work. When you have disasters, if you don't have access to legal services and lawyers that understand farmers, it's going to take people even longer to get back on their feet in these disaster zones. These were well-spent resources that ought to be uplifted by the people who funded and made the grant possible."

This is an excerpt of a grantee impact story found in the Disaster Philanthropy Playbook. Read the full story here. 


\section{Large U.S. Foundation Funding Trends, 2014-2018}

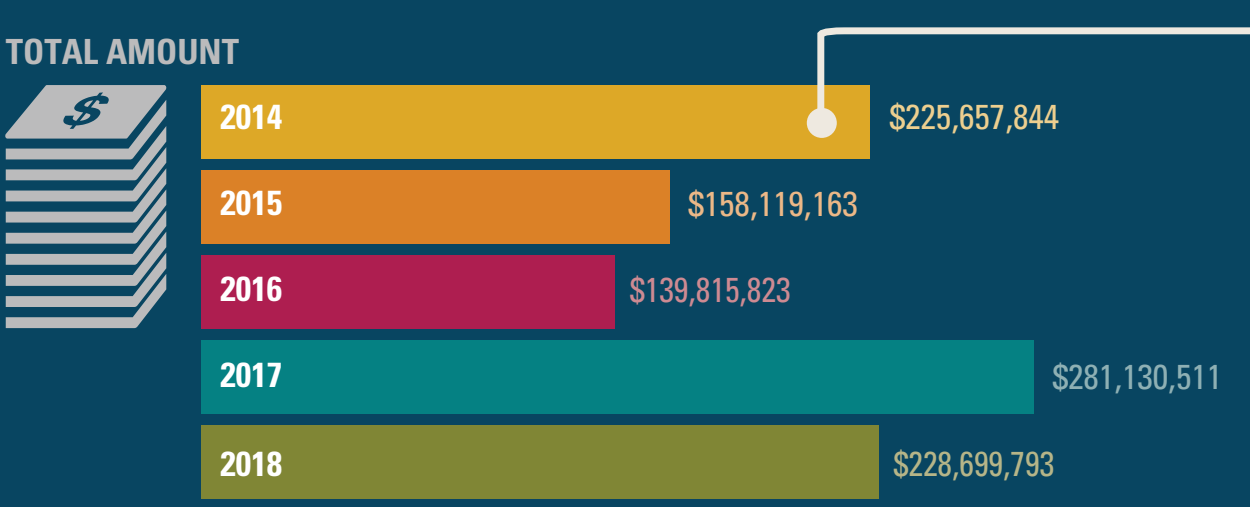

Increased funding in 2014 was due to large grants for the Ebola outbreak.

NUMBER OF GRANTS

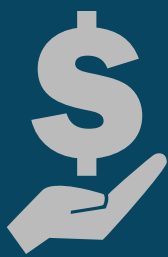

$2014 \quad 525$ grants

\begin{tabular}{|c|c|c|}
\hline 2015 & 740 grants & \\
\hline 2016 & 704 grants & \\
\hline 2017 & & 1,153 grants \\
\hline 2018 & & 1,122 grants \\
\hline
\end{tabular}

Many grants in 2017 addressed the devastation caused by Hurricanes Harvey, Irma, and Maria.

NUMBER OF FOUNDATIONS

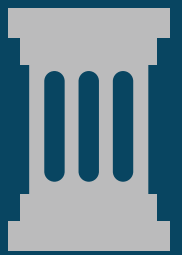

2014

\section{5}

2016

2017

2018
162 foundations

202 foundations

189 foundations

\section{4 foundations}

239 foundations

\section{About the Data}

Analysis of institutional philanthropy on page 6 is based on Candid's entire database of publishable transactions. Although the data offers the broadest picture of Candid's data on philanthropic giving, data availability varies from year to year, and it does not represent a scientific sample.

For year-over-year trends (and for this five-year analysis), we use a research set of all grants of $\$ 10,000$ or more reported by around 1,000 of the largest U.S. foundations. The data set does not include gifts by corporate giving programs or public charities. It also excludes grants, fellowships, or awards to individuals; grants paid by foundations to U.S. community foundations (to avoid double counting of dollars); and loans and program-related investments. 


\section{Other Data Sources}

\section{OECD DAC DONORS, 2018}

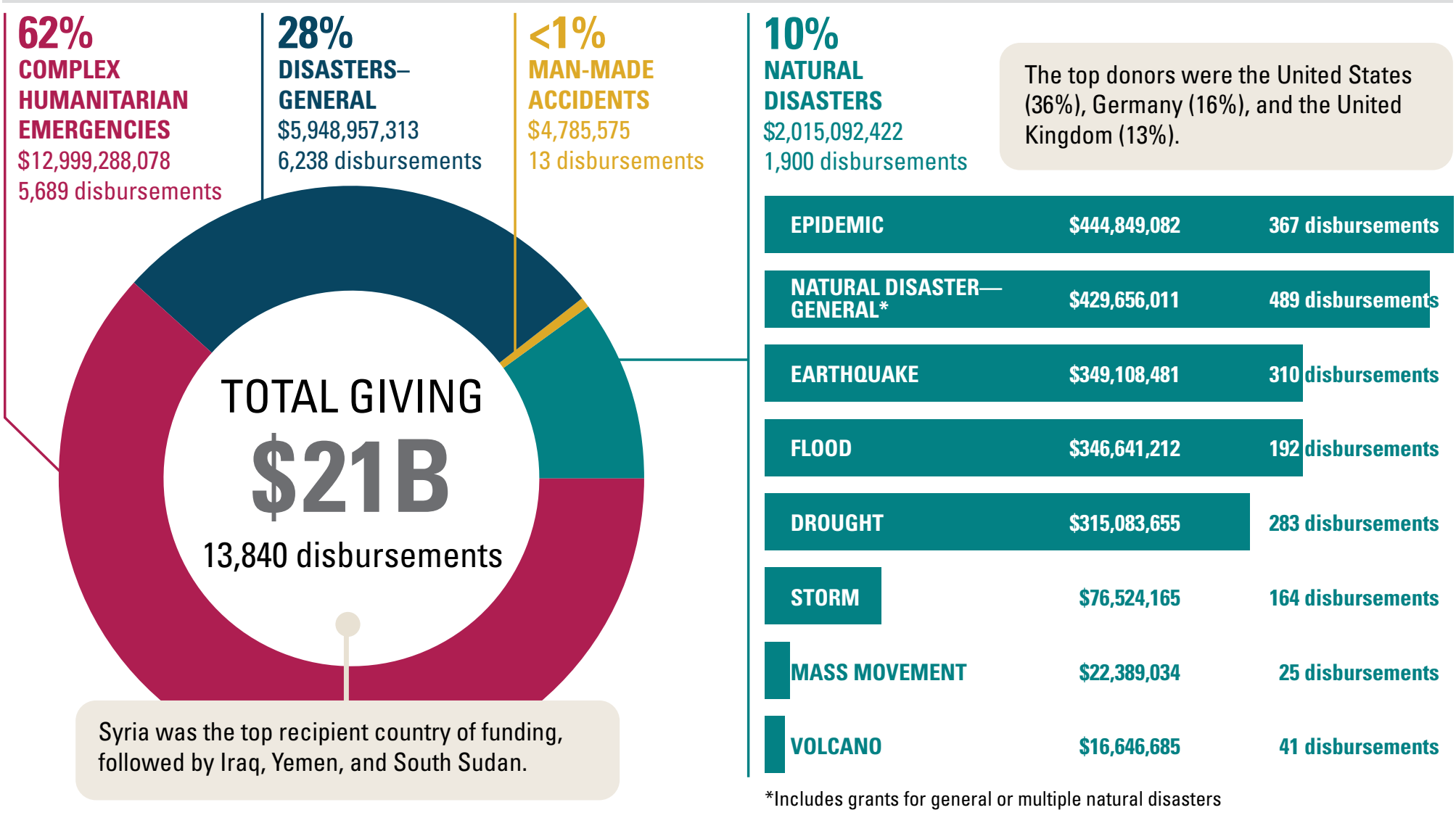

\section{UN OCHA, NON-DAC DONORS, 2018}

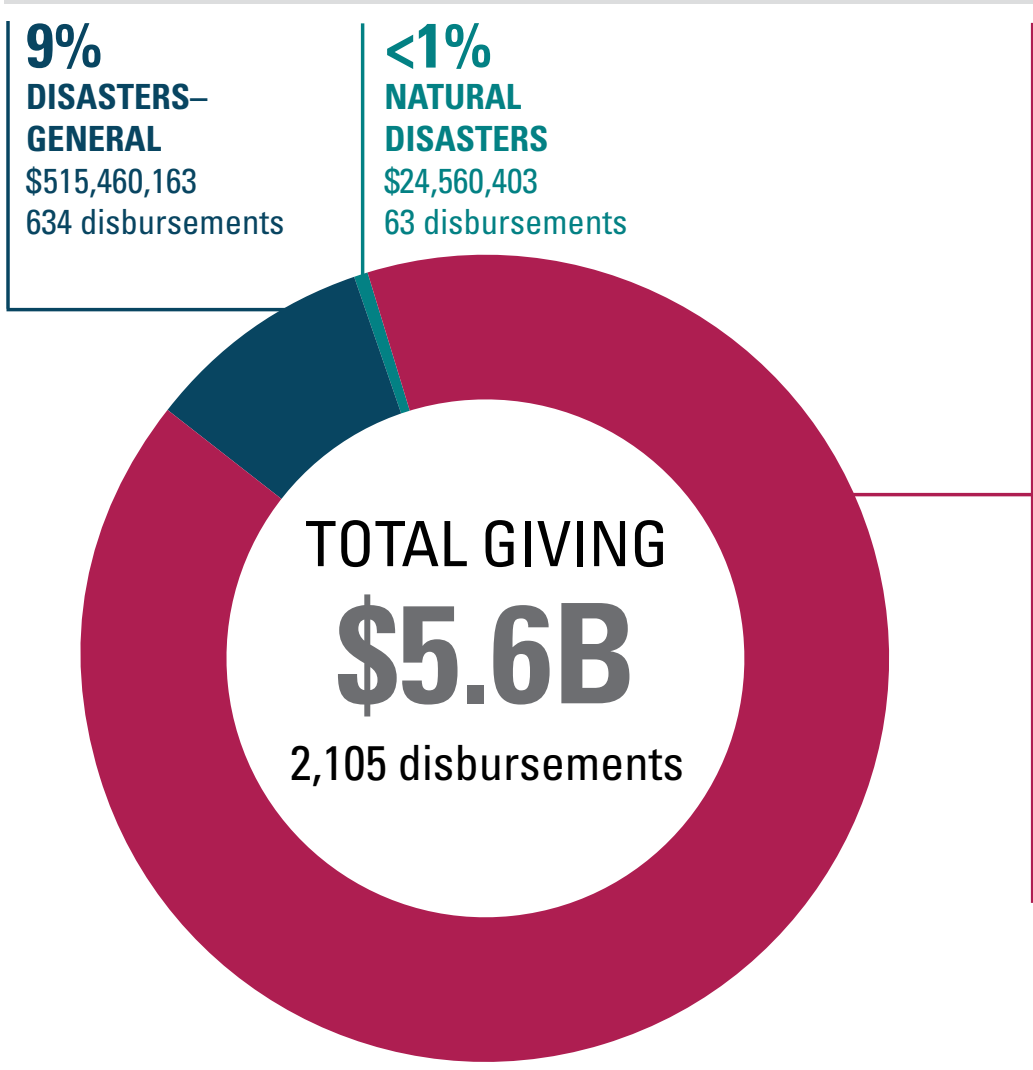

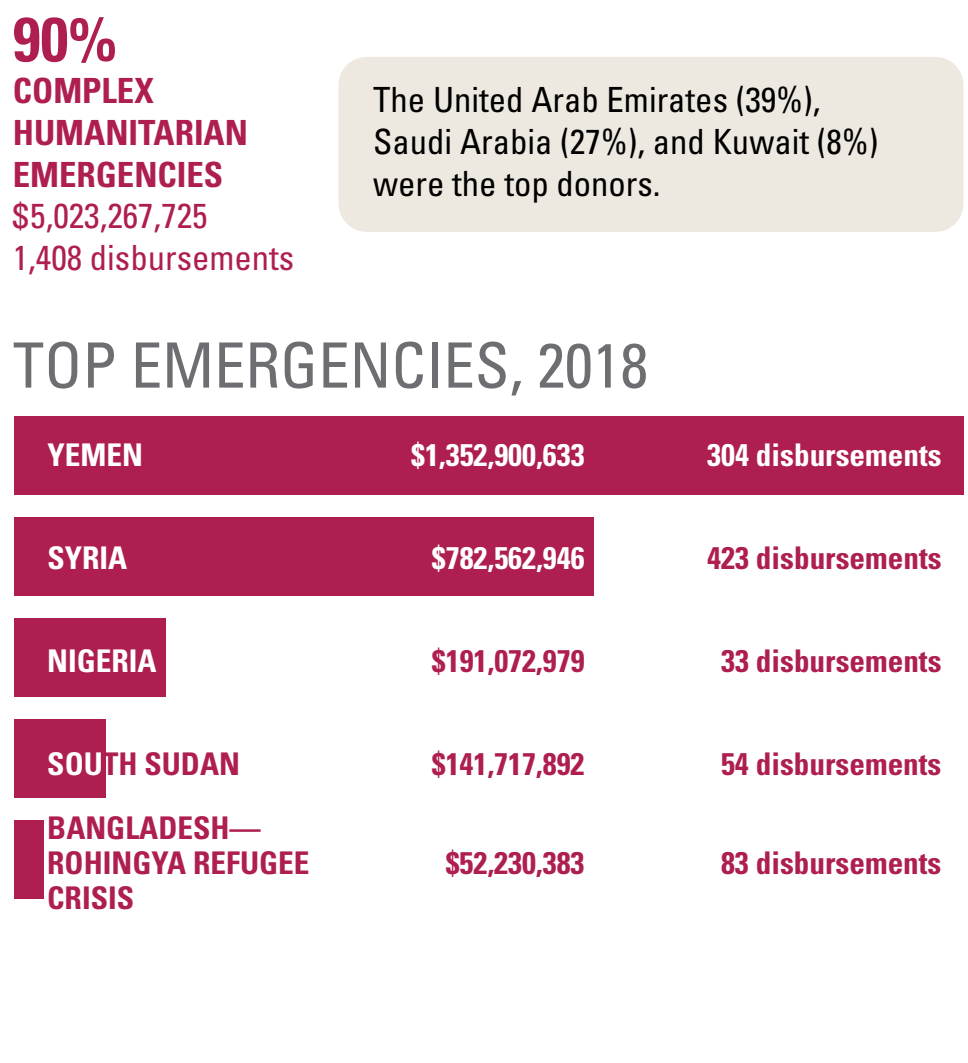




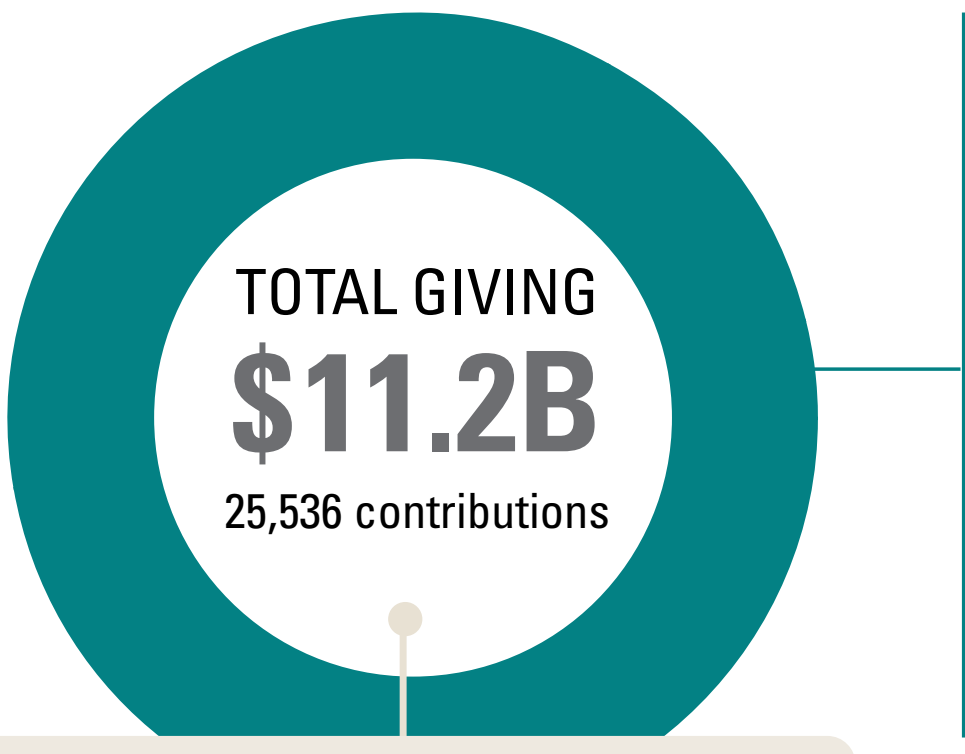

\begin{tabular}{|lrr|}
\hline STORMS & $\$ 9,005,394,562$ & 17,329 contributions \\
\hline WILDFIRE & $\$ 1,368,309,790$ & 3,043 contributions \\
\hline $\begin{array}{l}\text { FLOOD } \\
\text { NATURAL DISASTER- } \\
\text { GENERAL* }\end{array}$ & $\$ 623,197,461$ & 4,648 contributions \\
$\begin{array}{l}\text { MASS MOVEMENT } \\
\text { VOLCANO }\end{array}$ & $\$ 21,404,272$ & $\mathbf{3 8 6}$ contributions \\
\hline EARTHOUAKE & $\$ 15,488,229$ & $\mathbf{8 8}$ contributions \\
\hline $2,053,080$ & 11 contributions
\end{tabular}

The top recipient locations were Puerto Rico, Virgin Islands, and California.

\section{EDA, 2018}

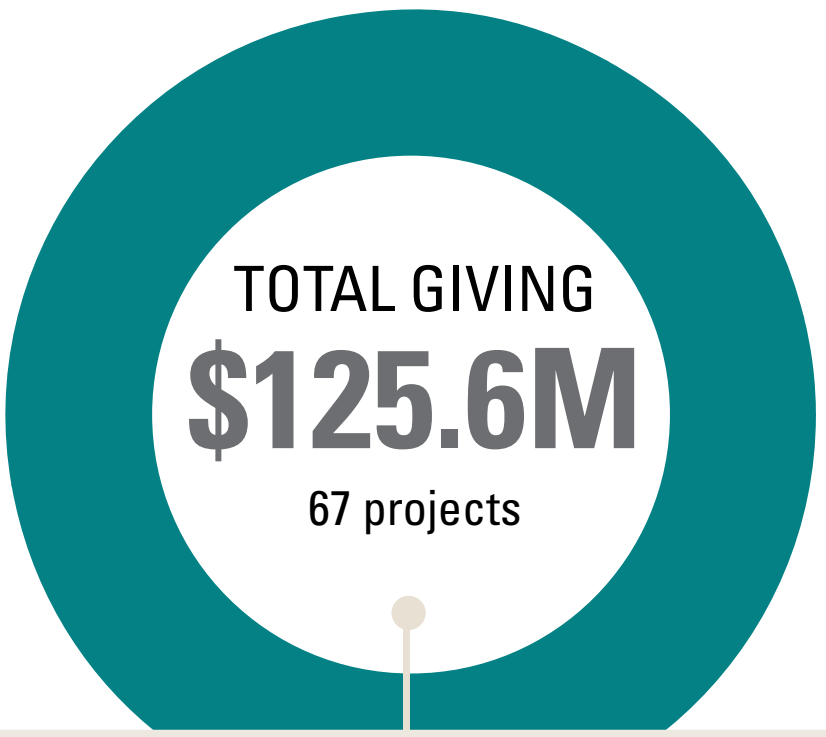

In 2018, the U.S. Economic Development Administration (EDA) invested approximately $\$ 125.6$ million in 67 projects that supported a variety of activities, including infrastructure, planning, research, technical assistance, and access to capital, to help communities and regions recovering from Hurricanes Harvey, Maria, Irma, or other major disasters build the capacity for economic development.

The EDA data should be viewed as a snapshot of the data available at the time of the data request (September 22, 2020) and is subject to any changes or updates as reflected within future reports and data requests.
*Includes grants for general or multiple natural disasters.

Data was accessed in July 2020 from fema.gov. FEMA and the federal government cannot vouch for the data or analyses derived from the data after it has been retrieved from the agency's websites.

\section{HUD, 2018}

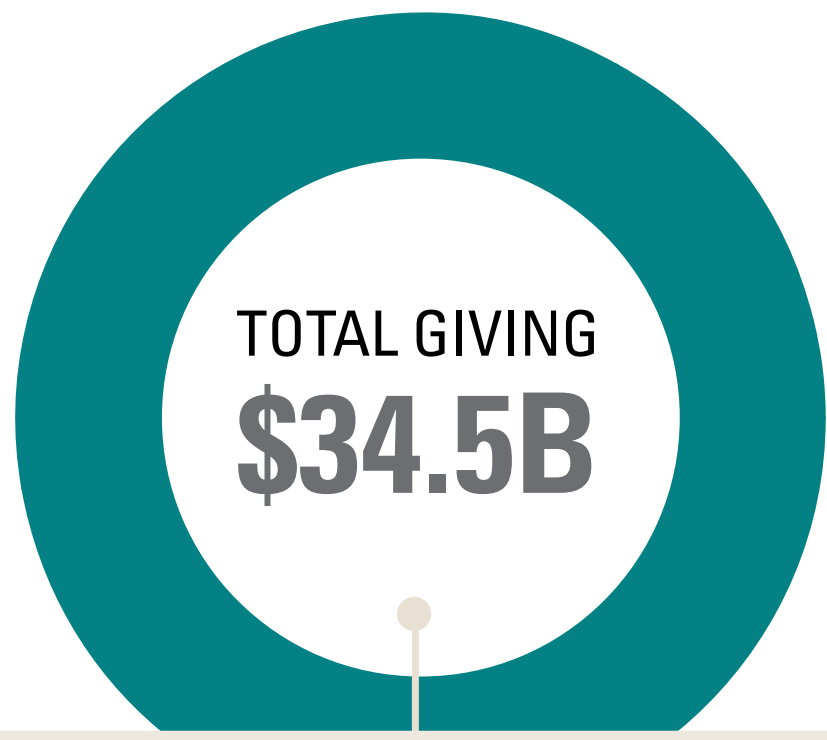

The U.S. Department of Housing and Urban Development (HUD) distributed $\$ 34.5$ billion in 2018 to states and local governments to recover from 2016 and 2017 disasters, which included Hurricanes Harvey, Irma, and Maria, and the Louisiana Floods, among other events. Grantees directed that money toward eligible disaster recovery activities, including housing rehabilitation, public improvements, and economic development. 


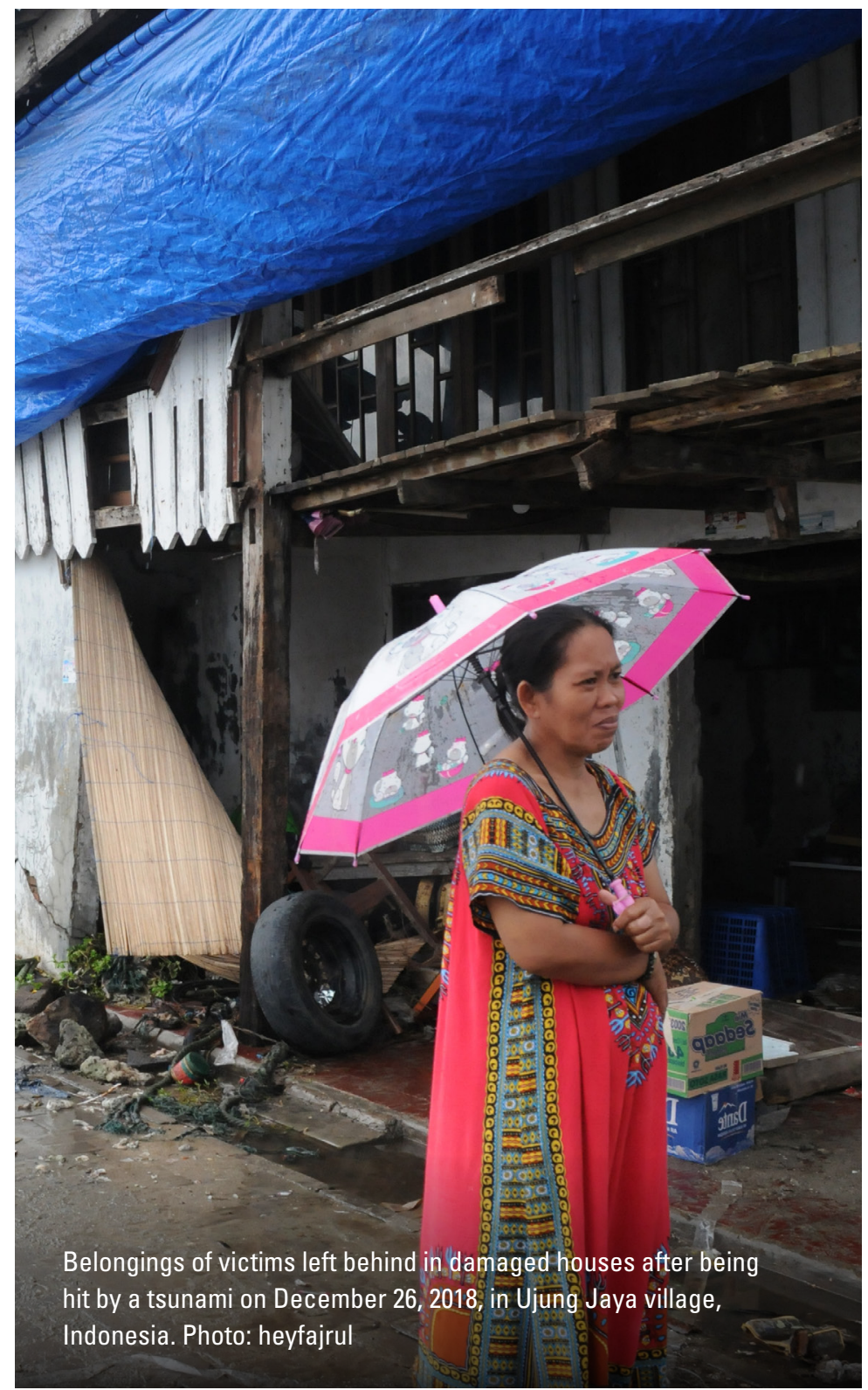

According to survey data in Giving in Numbers: 2019 Edition, published by the Chief Executives for Corporate Purpose (CECP), 242 of the world's largest companies directed an estimated \$206 million toward disaster relief in 2018. Disaster relief saw substantial gains in terms of median cash giving from 2016 to 2018. Median cash giving of disaster relief, however, was approximately just 15 percent of median cash giving in the top program area (health and social services).

\section{Disaster Giving by Industry, 2018}

\begin{tabular}{|lr}
\hline Health care & $\$ 86,345,000$ \\
\hline Financials & $\$ 37,520,000$ \\
\hline Consumer discretionary & $\$ 20,003,200$ \\
\hline Consumer staples & $\$ 19,421,600$ \\
\hline Industrials & $\$ 16,120,000$ \\
\hline Technology & $\$ 12,784,200$ \\
\hline Energy & $\$ 9,739,200$ \\
\hline Utilities & $\$ 3,281,000$ \\
\hline Materials & $\$ 772,800$ \\
\hline
\end{tabular}

\section{MORE ON CORPORATE GIVING TRENDS FROM CANDID'S DATABASE}

\section{CORPORATE GIVING FOR SPECIFIC DISASTERS, 2018}

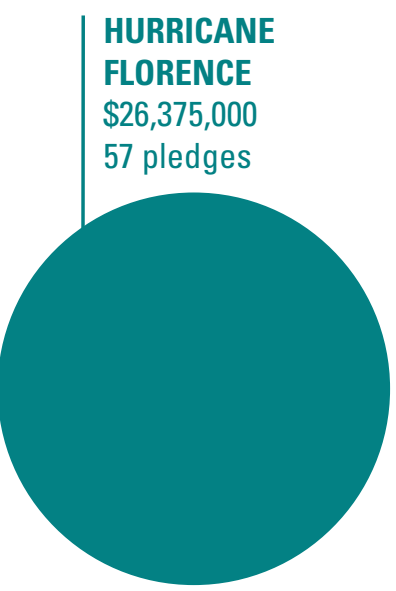

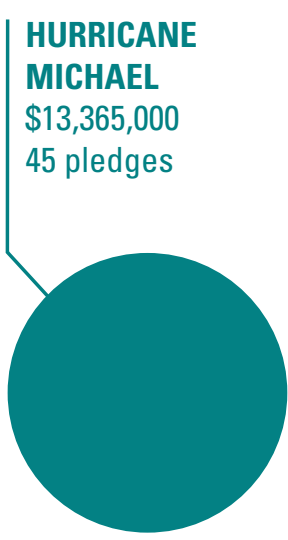

Nike Foundation gave a $\$ 125,000$ grant to CDP's 2018 Atlantic Hurricane Season Recovery Fund. Starbucks Foundation provided CDP with $\$ 100,000$ to support its response to the Kerala floods. 


\section{U.S. HOUSEHOLD DISASTER GIVING, 2018}

In 2018, the U.S. experienced the fourth-costliest year of major natural disasters on record. These disasters included the devastating wildfires in California and Hurricanes Florence and Michael—in addition to major flooding events, tornadoes, and winter storms.

The Center for Disaster Philanthropy, Candid, and the Indiana University Lilly Family School of Philanthropy conducted an online survey of U.S. households in March 2019 about household charitable donations in support of disaster aid efforts in 2017 and 2018. A total of 1,243 households completed the survey. All findings can be found in the report U.S. Household Disaster Giving in 2017 and 2018.

\section{TOP DISASTERS SUPPORTED}

\section{\% of U.S. Households in 2018}

\begin{tabular}{|c|c|}
\hline California wildfires & $11 \%$ \\
\hline Hurricane Michael & $9 \%$ \\
\hline Hurricane Florence & $8 \%$ \\
\hline Continued support for 2017 disasters & $5 \%$ \\
\hline Africa \& Middle East food crisis & $4 \%$ \\
\hline $\begin{array}{l}\text { Continued support for disasters } \\
\text { that occurred prior to } 2017\end{array}$ & $3 \%$ \\
\hline
\end{tabular}

DISASTER GIVING VS. GIVING TO OTHER CAUSES

\section{Among U.S. Households That Made a Charitable Donation in 2018}

\begin{tabular}{lc} 
Gave to non-disaster-related activities only & $61 \%$ \\
\hline $\begin{array}{l}\text { Gave to both disaster-related and } \\
\text { non-disaster-related activities }\end{array}$ & $35 \%$ \\
\hline Gave to disaster aid efforts only & $4 \%$ \\
\hline
\end{tabular}

Key findings for 2018 include:

- Twenty-nine percent of U.S. households made a disaster-related donation, averaging $\$ 83$ per household. We can infer from this figure that U.S. households may have donated as much as \$3 billion to disaster aid efforts in 2018.

- Top motivations for disaster giving were the magnitude of the disaster (the scale of the event and the number of people affected), personal connections to the location of the disaster, and media coverage.

- In 2018, 5 percent of households donated to support recovery from disasters that occurred in 2017, which was the costliest year of major natural disasters in the U.S. on record.

- Twenty-two percent of households donated to U.S. disasters, and 7 percent donated to disasters that occurred outside the U.S

- Among households that made a charitable donation, only 4 percent allocated all their charitable contributions to disasterrelated activities.

- Thirty-five percent of households donated to both disasterrelated and non-disaster-related activities.

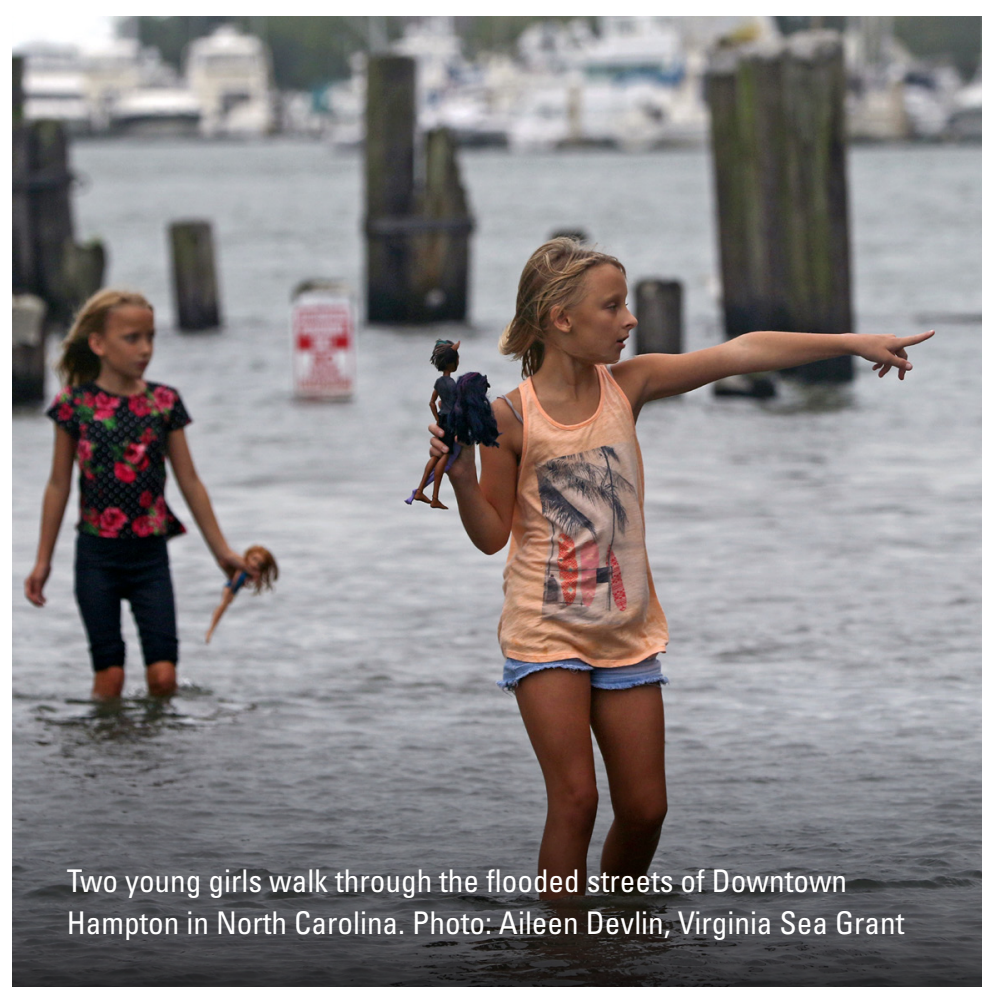




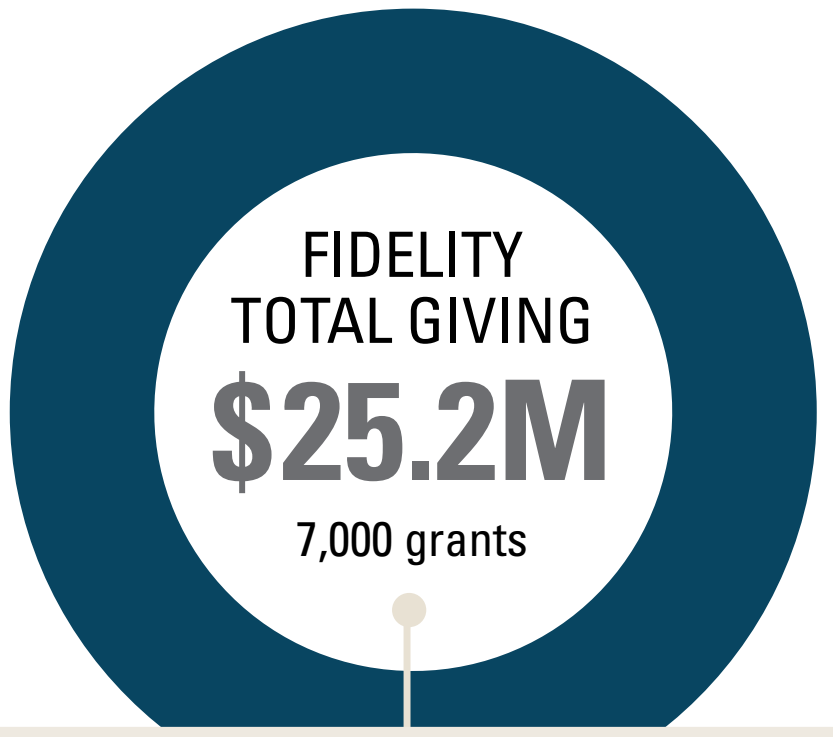

Some $\$ 8.6$ million (4,000 grants) went toward Hurricanes Florence and Michael; more than $\$ 11.7$ million went toward the global refugee crisis.

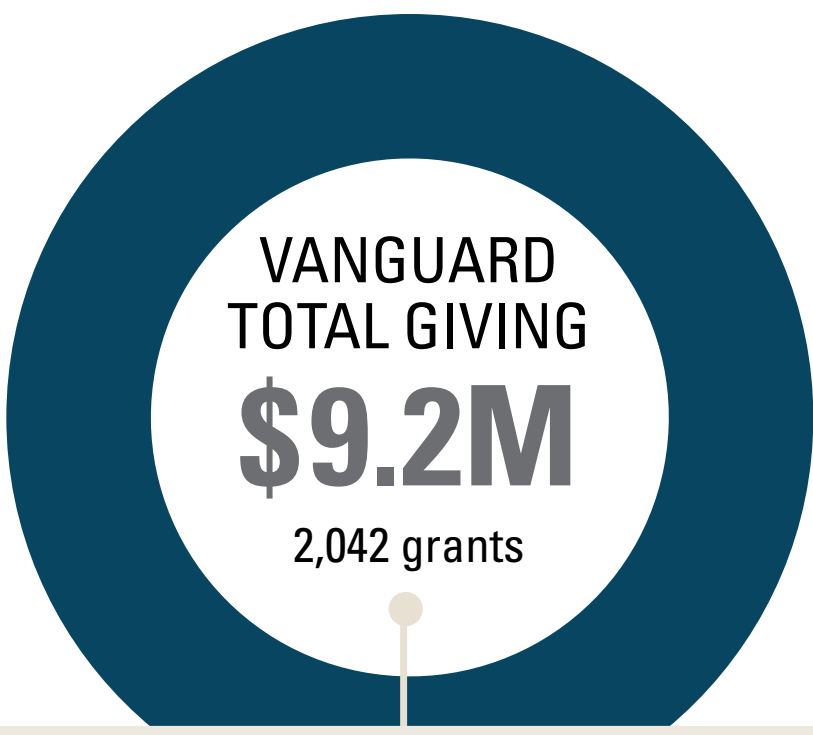

Some \$3.3 million (547 grants) went toward complex humanitarian emergencies, and $\$ 2.2$ million went toward storms (606 grants).

This section provides a small snapshot of money flowing to disasters from donor-advised funds, as Fidelity Charitable and Vanguard Charitable are just two of the many donor-advised fund management companies.

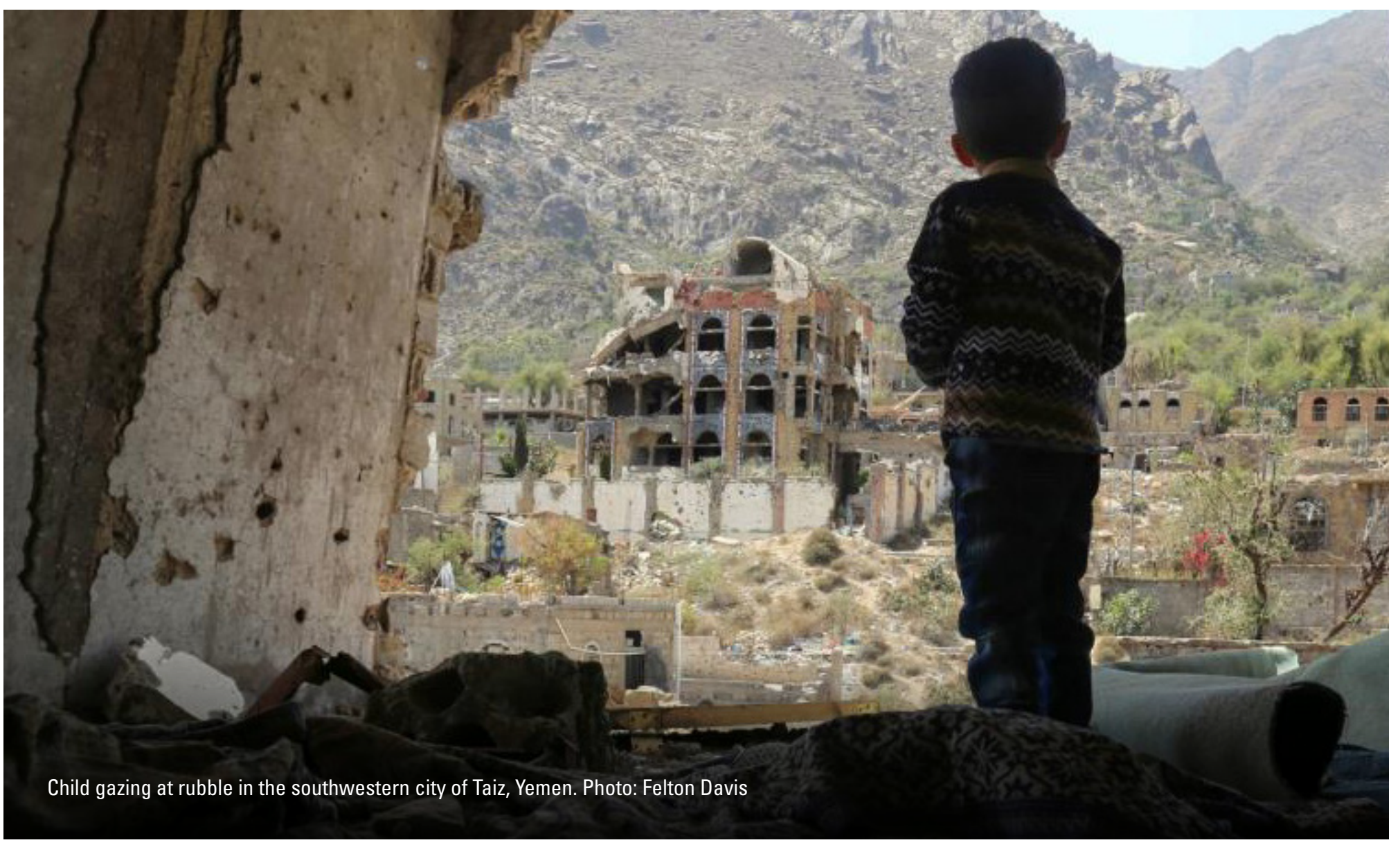




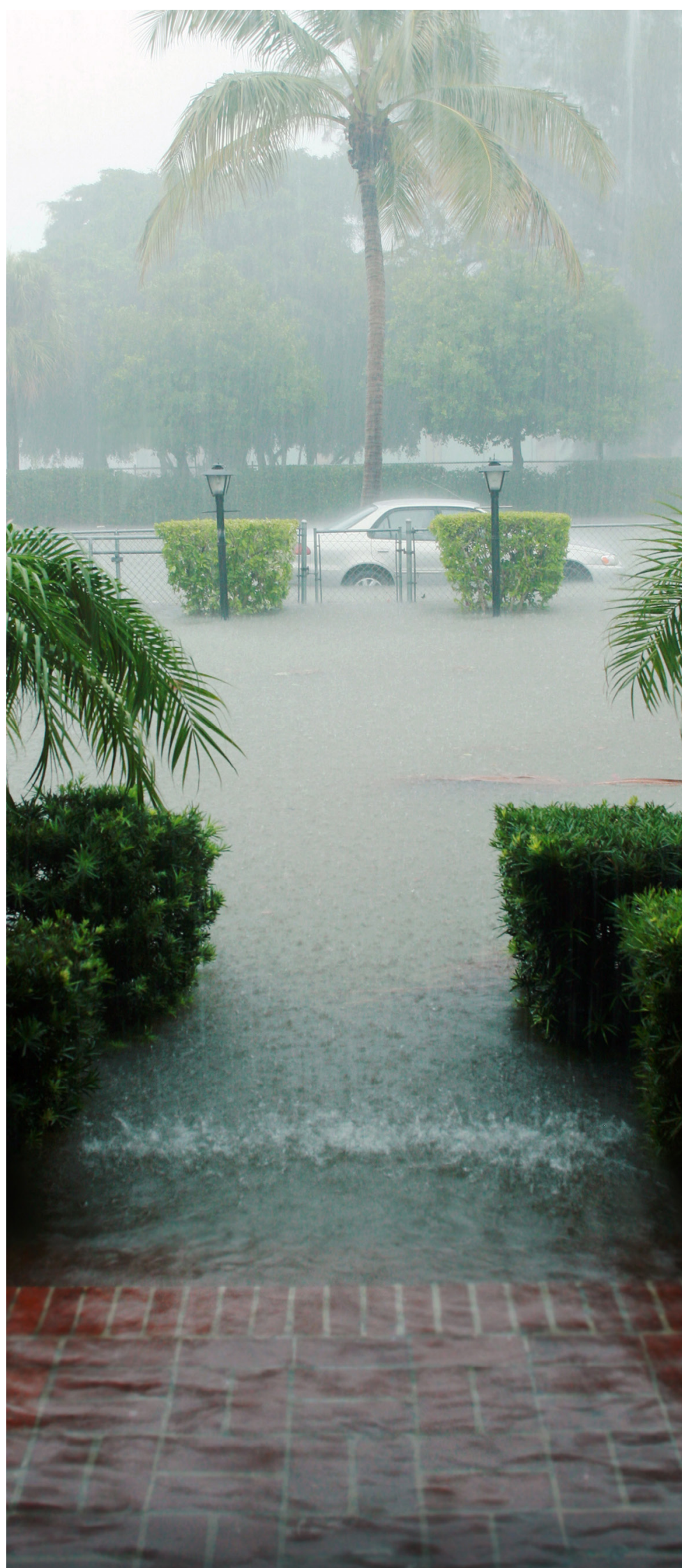

Heavy rains and stormy weather floods a residential lawn and porch in Miami, Florida. Photo: tovfla

\section{GLOBALGIVING, 2018}

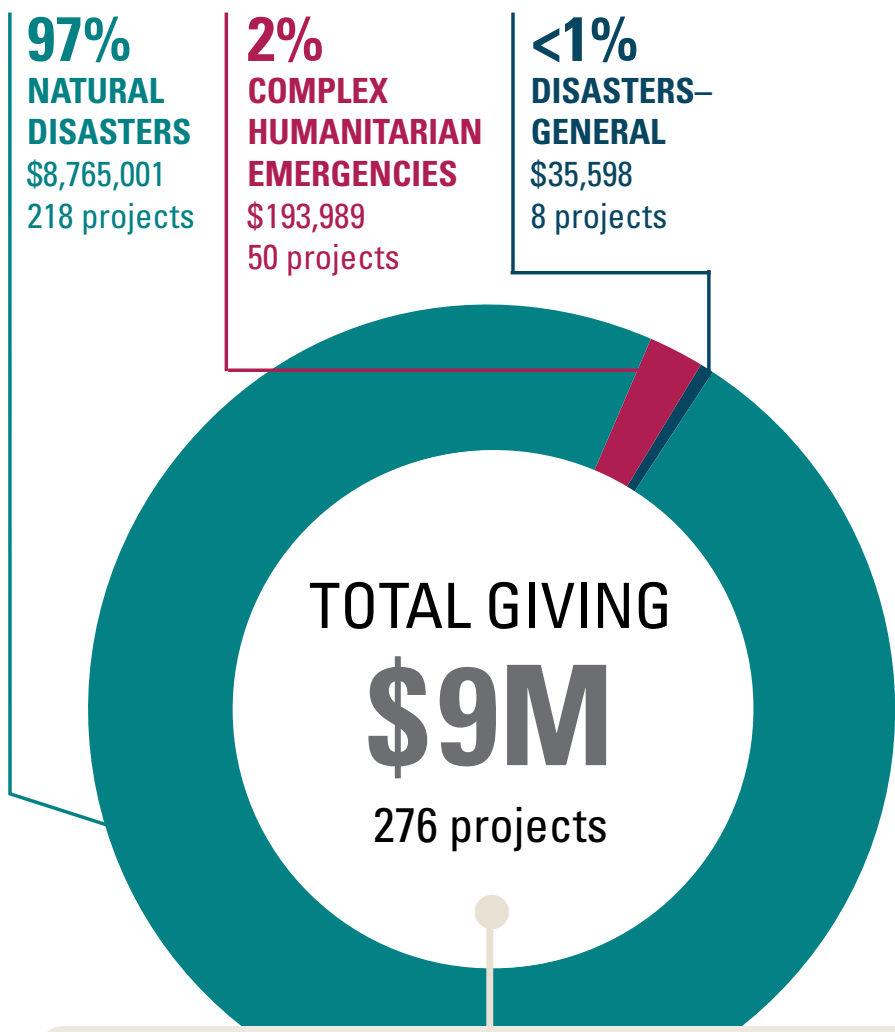

The top-funded disasters were Hurricane Maria, the California wildfires, Hurricane Florence, Hurricane Michael, and the Indonesia earthquake and tsunami.

\section{NETWORK FOR G00D, 2018}

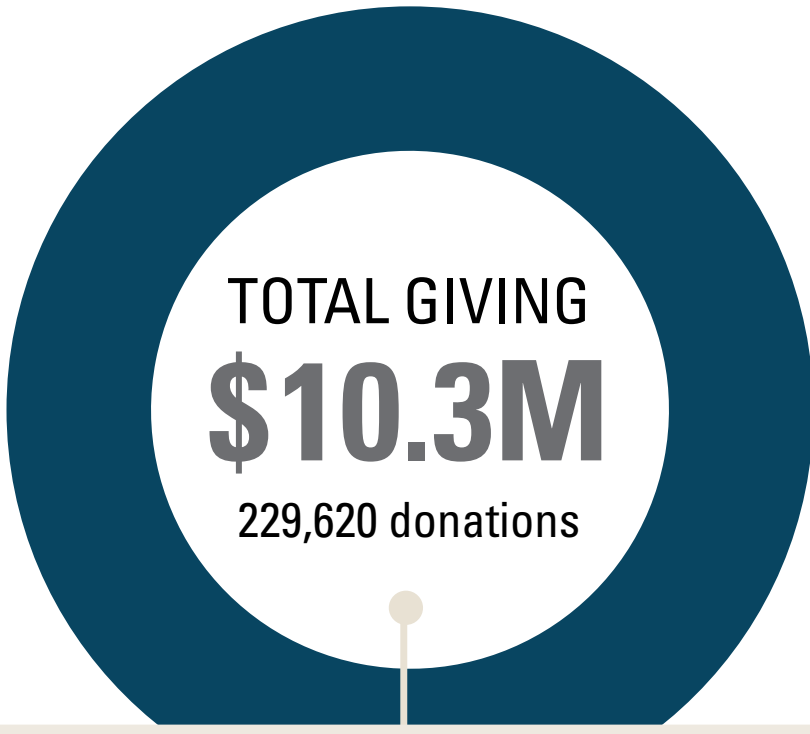

Of the $\$ 405.4$ million in donations made through Network for Good's online platform in 2018, \$10.3 million went to disaster-related organizations. This amount represents 3 percent of total giving on the platform. 


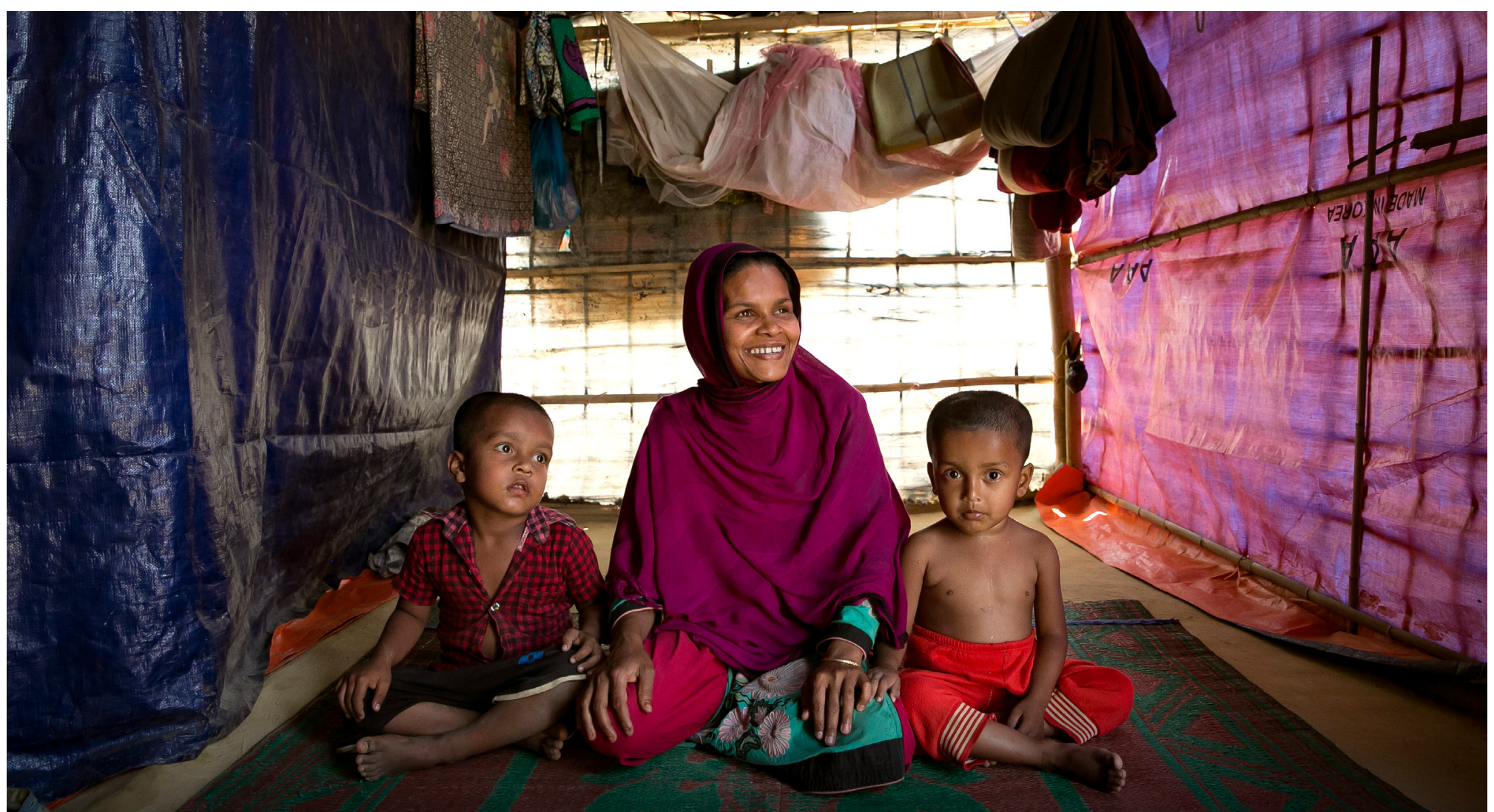

A woman sits with her children in Balukhali camp in Cox's Bazar. Photo: Allison Joyce, UN Women

\section{Closing Thoughts}

This report aims to provide a comprehensive picture of what disaster giving looked like in 2018, so that donors can be strategic in their future disaster-related philanthropy. Institutional and individual philanthropy plays an essential role in helping communities prepare for, and respond to, global disasters and humanitarian crises.

Now more than ever, as the world continues to cope with COVID-19, it is important that philanthropic actors consider how they can best maximize their disaster-related giving. And although it is vital to channel funds toward immediate relief soon after a disaster strikes, philanthropy also needs to support preparedness and mitigation efforts to help reduce the overall impact of disasters on communities. Additionally, philanthropy can also provide communities with much-needed sustained funding for the long road to recovery, months or even years after a disaster has passed.

We acknowledge that there are many more disaster contributions than what we currently document. We welcome donors, government agencies, and other organizations to partner with us to include their giving data in our annual analysis.

\section{To learn more about Measuring The State Of Disaster} Philanthropy, we invite you to visit our online toolsincluding an interactive dashboard and funding mapat disasterphilanthropy.candid.org. To learn about the best ways to allocate resources for disasters, visit disasterplaybook.org. 


\section{Contributors}

\section{CANDID}

Emilia Charno, Suzanne Coffman, Kathye Giesler, Andrew Grabois, Naomi Henry-Salami, Supriya Kumar, Guy Mika, Izzi Nesci, Matthew Ross, Betty Saronson, Grace Sato

\section{CENTER FOR DISASTER PHILANTHROPY}

Ruja Entcheva, Tanya Gulliver-Garcia, Yna Moore, Regine A. Webster

\section{WE ARE GRATEFUL TO THE FOLLOWING INDIVIDUALS FOR SHARING THEIR TIME, EXPERTISE, AND DATA}

- Community Organized Relief Effort: Ann Lee

- Fidelity Charitable: Jessica Belsky, Argha Bose, Susan Shell

- Land Loss Prevention Project: Savonala "Savi" Horne

- Network for Good: Elicia Potter, Alex Wigmore

- North Valley Community Foundation: Kim DuFour, David Little

- The UPS Foundation: Alice Turner

- U.S. Department of Housing and Urban Development (HUD): Rosie Beaman, Joseph Slaughter

- U.S. Economic Development Administration (EDA): Naomi Friedman

- U.S. Federal Emergency Management Agency (FEMA): Amber Noel

- Vanguard Charitable: Victoria Kelberer, Nathan Schumann

This report was produced with generous funding by The Leona M. and Harry B. Helmsley Charitable Trust.

Front cover: A Lassen Hotshot pauses during a burning operation in California. Photo: Mike McMillan, USFS

Copyright (C) 2020 Candid and the Center for Disaster Philanthropy.

This work is made available under the terms of the Creative Commons Attribution-NonCommercial 4.0 Unported License, creativecommons.org/licenses/by-nc/4.0

doi.org/10/ghfsfv 